\title{
Modeling the exhumation path of partially melted ultrahigh- pressure metapelites, North-East Greenland Caledonides
}

\author{
Helen M. Lang ${ }^{1, *}$ and Jane A. Gilotti ${ }^{2}$
}

${ }^{1}$ Department of Geology and Geography, 330 Brooks Hall, West Virginia University, Morgantown, WV 26506-6300, USA, Helen.Lang@mail.wvu.edu

${ }^{2}$ Department of Earth and Environmental Sciences, 121 Trowbridge Hall, University of lowa, lowa City, IA 52242, USA, jane-gilotti@uiowa.edu

*Corresponding author: Tel.: +1 304 2935469; fax: +1 3042936522 


\section{Abstract}

Pseudosection modeling constrains the pressure-temperature $(P-T)$ exhumation path of partially melted ultrahigh-pressure (UHP) metapelites exposed in the North-East Greenland UHP terrane. A robust peak $P$ and $T$ estimate of $3.6 \mathrm{GPa}$ and $970^{\circ} \mathrm{C}$ based on mineral assemblages in nearby kyanite eclogites is the starting point for the $P-T$ path. Although the peak assemblage for the metapelite is not preserved, the calculated modeled peak assemblage contained substantial clinopyroxene, garnet, phengite, K-feldspar and coesite with minor kyanite and rutile. Combining the pseudosection and observed textures, the decompression path crosses the coesite-quartz transition before reaching the dry phengite dehydration melting reaction where phengite is abruptly consumed. In the range of 2.5 to $2.2 \mathrm{GPa}$, clinopyroxene is completely consumed and garnet grows to its maximum volume and grossular content, matching the high grossular rims of relict megacrysts. Plagioclase joins the assemblage and the pseudosection predicts up to $12-13$ volume $\%$ melt in the supersolidus assemblage, which contained garnet, liquid, K-feldspar, plagioclase, kyanite, quartz and rutile. At this stage, the steep decompression path flattened out and became nearly isobaric. The melt crystallization assemblage that formed when the path crossed the solidus with decreasing temperature contains phengite, garnet, biotite, 2 feldspars, kyanite, quartz and rutile. Therefore, the path must have intersected the solidus at approximately $1.2 \mathrm{GPa}, 825^{\circ} \mathrm{C}$. The pseudosection predicts that garnet is consumed on the cooling path, but little evidence of late garnet consumption or other retrograde effects is observed. This may be due to partial melt loss from the rock. Isochemical $P T-n$ and $P T-X$ sections calculated along the $P-T$ path display changes in mineral assemblage and composition that are consistent with preserved assemblages.

Keywords: ultrahigh-pressure; metapelites; partial melting; pseudosections; Caledonides; Greenland 


\section{Introduction}

Fluids and partial melts play an important role in the formation and exhumation of continental crust in ultrahigh-pressure (UHP) terranes (Hermann et al., 2013; Hermann and Rubatto, 2014; Zheng et al. 2011). At UHP conditions, phengite is the only stable, hydrous phase in crustal rocks of common bulk compositions (Hermann and Green, 2001; Massonne, 2009; Schmidt et al., 2004). The large stability field of phengite precludes dehydration melting at UHP conditions, except perhaps in the hottest of the diamond-bearing terranes, such as the Kokchetav massif, Kazakhstan and the Erzgebirge area of the Bohemian massif (Hermann and Rubatto, 2014). Dehydration melting of phengite is more likely to take place on the steep, decompression segment of the $P-T$ path after considerable exhumation to quartz stable conditions above $700^{\circ} \mathrm{C}$. Peak conditions for most UHP terranes fall the field of hydrous melting, but melting will only occur at $\mathrm{H}_{2} \mathrm{O}$ saturated states (e.g. Labrousse et al., 2011), which is considered unlikely because continental UHP terranes are typically dry (Hermann and Rubatto, 2014). Many of the leucocratic melts seen in UHP terranes form by the introduction of hydrous fluid during the later stages of exhumation (Gilotti et al., 2014; Gordon et al., 2012; Labrousse et al., 2002).

In the North-East Greenland Caledonides (Fig. 1), relatively hot $\left(\approx 950^{\circ} \mathrm{C}\right.$ at $\left.3.6 \mathrm{GPa}\right)$ UHP conditions are documented by mineral assemblages, microstructures and thermobarometry on kyanite eclogites (Gilotti and Ravna, 2002), and by coesite inclusions in zircon (Gilotti et al., 2014; McClelland et al, 2006). However, the exhumation path from UHP conditions has only been estimated (Gilotti and McClelland, 2007). Evidence of partial melting is preserved in rare pelitic paragneisses that contain garnet megacrysts with complex compositional zoning and polyphase inclusions, and abundant leucosomes in the matrix (Lang and Gilotti, 2007). No coesite has been found in the paragneiss; however, they are in close proximity to coesite-bearing eclogites and orthogneisses (Fig. 1), so we assume that the paragneisses experienced the same UHP conditions. The metapelites preserve considerable 
evidence for different stages along the exhumation path, including the transformation of coesite to quartz, melting, changes in mineral assemblages and pronounced garnet zoning.

Here we examine two pelitic paragneisses from the North-East Greenland UHP terrane in relation to calculated pseudosections (de Capitani and Petrakakis, 2010; Powell and Holland, 1988; White et al., 2001, 2007) in order to establish their decompression and cooling path. The pseudosection approach makes it possible to follow changes in mineral assemblages and composition through the entire metamorphic history in rocks that are exposed to dramatically changing conditions during their post-peak evolution (e.g. Menold et al., 2009). The Greenland metapelites are ideally suited the pseudosection approach because zoned garnet megacrysts are well preserved, phengite relicts exist, partial melting has been demonstrated and retrogression to amphibolite facies assemblages is minimal. Our results show that dehydration melting of phengite occurred just below the coesite to quartz transition, after exhumation had begun.

\section{Geologic Setting}

The East Greenland margin is part of Laurentia (Higgins et al., 2008), which formed the overriding plate in a Paleozoic collision with Baltica during the Caledonian orogeny. The continental crust of Baltica, represented by the HP and UHP terranes of the Western Gneiss Region, Norway, was subducted beneath Laurentia from approximately 420-400 Ma (e.g. Hacker et al., 2010). During this time, the crust of Laurentia thickened and is marked by widespread HP metamorphism. The North-East Greenland eclogite province (NEGEP) covers an area of over $40,000 \mathrm{~km}^{2}$ and comprises the uppermost thrust sheet in the northern segment of the Greenland Caledonides (Gilotti et al., 2008). The NEGEP is a parcel of the Precambrian basement of Laurentia that was deformed and metamorphosed at HP from 410-390 Ma (Gilotti et al., 2004), as a result of crustal thickening of the overriding plate in response to collision. The 
thickening is analogous to the present day 60-90 km thickness of the Tibetan plateau (Mechie et al., 2012, Wittlinger et al., 2004), which lies in the upper plate of the Himalayan orogeny. An UHP terrane of unknown dimensions is exposed on a small island in Jøkelbugt, informally known as Rabbit Ears Island (REI, Fig. 1). The island lies at $78^{\circ} \mathrm{N}$, at the exposed eastern margin of the North-East Greenland eclogite province. The UHP terrane is composed of the same Laurentian crust that comprises the large NEGEP (Gilotti and McClelland, 2011), i.e. a 2.0-1.8 Ga calc-alkaline intrusive complex that was deformed, metamorphosed and subsequently intruded by 1.75 anorogenic granites (Kalsbeek et al., 2008). Rare, discontinuous layers of paragneiss are also present in the NEGEP (Hull et al., 1994). Coesite inclusions in zircon are documented in eclogite and felsic host gneiss on REl; U-Pb zircon geochronology by ion probe on the exact domains that contain coesite show that UHP metamorphism occurred from 365-350 Ma (McClelland et al., 2006), much later than the HP metamorphism. UHP metamorphism late in the collision in the overriding plate may have formed by intracontinental subduction, where lithosphere-breaking strike-slip faults subjected to continued plate convergence brought the already thickened Laurentian crust down to mantle depths (Gilotti and McClelland, 2007).

The North-East Greenland eclogite province and UHP terrane are typical of continental eclogite terranes worldwide (Chopin, 2003; Gilotti 2013), where small mafic enclaves of eclogite are surrounded by quartzofeldspathic orthogneisses, paragneisses and other metasedimentary rocks. Eclogite blocks on REI are meters to tens of meters long and compositionally layered, suggesting that their protoliths were layered mafic intrusive complexes. The host orthogneisses are garnet-rich, and many of them contain clinopyroxene and kyanite, relicts of their HP history. Elvevold and Gilotti (2000) established a robust, clockwise, hairpin shaped P-T path for a kyanite eclogite locality in the HP rocks of the NEGEP using inclusion suites and textural relations. Kyanite eclogites from the UHP rocks on Rabbit Ears Island give peak P-T conditions of approximately 3.6 GPa and $950^{\circ} \mathrm{C}$ (Gilotti and Ravna, 2002), but a rigorous path for the UHP 
terrane is lacking. The metapelites in the UHP terrane, which are the focus of this study, outcrop in two small lenses $(<100 \mathrm{~m}$ long and $20 \mathrm{~m}$ wide) surrounded by orthogneiss with concordant contacts (Fig. 1). The discovery of coesite in one of the host gneisses and the coherent nature of the terrane supports our assumption that all the rocks on REI experienced UHP metamorphism. The metapelites, though rare, are important because they retain evidence of partial melting due to phengite breakdown (Lang and Gilotti, 2007) along a critical part of the exhumation path while the terrane was still at high pressure.

Gilotti and McClelland (2007) suggested that partial melting began at approximately 347 $\mathrm{Ma}$, based on U-Pb ages from a garnet-bearing granitic pegmatite in the neck of a boudinaged eclogite. Later, cross-cutting leucosomes, with and without hornblende, give younger U-Pb zircon ages that range from about $340 \mathrm{Ma}$ down to $320 \mathrm{Ma}$ (errors on individual ages range from 2-5 Ma; Gilotti and McClelland, 2007; Gilotti et al., 2014; McClelland et al., 2009). These late leucocratic layers and dikes are thought to form via fluid assisted melting from the introduction of external fluids (e.g. Prince et al., 2001; Rubatto et al., 2009) when the UHP terrane had reached amphibolite facies conditions. The Greenland UHP terrane, as well as the larger HP North-East Greenland eclogite province, has clearly experienced a long and varied melting history along the exhumation path (Gilotti et al., 2014).

\section{Sample Description}

Two samples of pelitic paragneiss, 03-126 and 03-127 (Fig. 1, 2a), collected from the same outcrop within a few meters of each other, were chosen for detailed study and phase equilibria modeling. Mineral chemistry and compositional maps were obtained using the Cameca SX-100 electron microprobe at Rensselaer Polytechnic Institute in Troy, New York. Mineral abbreviations are after Whitney and Evans (2010).

The paragneiss outcrop contains a $15-20 \mathrm{~cm}$ thick lens of segregated leucosome with residual garnet megacrysts and only minor biotite (Fig. 2a). Samples 03-126 and 03-127 were 
collected from the surrounding metapelitic rocks that contain smaller segregated leucosomes (Fig. 2a). The groundmass of both samples has a strong foliation that wraps around the garnet megacrysts. The leucocratic lenses are generally parallel to the foliation, but they cross-cut it in detail (Fig. 2a, b), supporting the inference that they represent partial melts. The samples contain abundant garnet megacrysts (up to $1.5 \mathrm{~cm}$ in diameter), have a strong gneissic foliation that is defined by quartz ribbons and anastomosing fine grained layers comprised of quartz, small garnets, white mica, plagioclase, K-feldspar, biotite and kyanite, which we interpret as crystallized melt. The quartz ribbons are interpreted as restite, similar to quartz in other anatectic metapelites (e.g. Indares et al., 2008). Both samples preserve abundant evidence of partial melting, which is described in detail elsewhere (Lang and Gilotti, 2007).

The cores of the garnet megacrysts are restitic and are interpreted to have grown at peak UHP conditions. Garnet cores commonly contain polycrystalline and lobate quartz inclusions (e.g. Waters, 2001), some with radial fractures that suggest former coesite. Many quartz inclusions are surrounded by thin rims of alternating plagioclase and K-feldspar that may have been former melt (Fig. 2c, d). Zoning in the garnet megacrysts (Fig. 3) is complex, but preserves relatively homogeneous cores with very low grossular $\left(X_{G r s}=0.05\right)$, moderate pyrope $\left(X_{\text {Prp }}=0.30\right)$ and high almandine $\left(X_{\text {Alm }}=0.65\right)$ content (Fig. $3 \mathrm{a}, \mathrm{b}$, and $\left.\mathrm{c}\right)$. Spessartine $\left(\mathrm{X}_{\mathrm{Sps}} \sim 0.006\right)$ is nearly undetectable and is not shown. Garnet rims and small matrix neoblasts, interpreted to have grown from or recrystallized in contact with melt (Lang and Gilotti, 2007), have substantially higher grossular and lower almandine and pyrope (Fig. 3a and d) than the garnet cores, although the grossular content decreases toward the outermost rims.

\section{Phase Equilibria Modeling}

\subsection{Modeling Technique}

Conventional thermobarometry provides a basic method for calculating the $P-T$ locations of metamorphic reactions (Spear, 1993). Recently, thermodynamic data and activity 
models for most of the phases of interest has become available (Berman, 1988; Holland and Powell, 1998; Powell and Holland, 1988), and data for magmatic liquids and an approach to modeling the activity-composition relationships of melts have been developed (White et al., 2001, 2007). The isochemical phase equilibria modeling or pseudosection technique makes it possible to calculate phase relations for a rock of a particular bulk composition over a wide range of $P-T$ conditions, using several different software packages (e.g. Connelly and Petrini, 2002; de Capitani and Petrakakis, 2010; Powell and Holland, 1988). We use the Theriak-

Domino program (de Capitani and Petrakakis, 2010) with an updated version of the Holland and Powell (1998) dataset (tcds55 file created on 22 Nov 2003, converted to Theriak-Domino format by D.K. Tinkham 23 Aug 2008), modified to include silicate melt following White and others (2007). The solution models used are: clinopyroxene (Green et al., 2007), white mica (Coggon and Holland, 2002), garnet (White et al., 2007), melt (melt 1, Holland and Powell, 1998 with White et al., 2007 updates), biotite (new TiBt, White et al., 2007) and feldspars (Cbar1 field, Holland and Powell, 2003).

\subsection{Modeling Conditions}

Bulk analyses for pseudosection modeling were obtained by XRF from Washington State University (Table 1). Large samples were crushed and homogenized, because the paragneisses are megacrystic and inhomogeneous. The two analyzed samples are in the range of "normal pelites" (Tinkham et al., 2001); 03-126 has slightly more $\mathrm{SiO}_{2}, \mathrm{Al}_{2} \mathrm{O}_{3}, \mathrm{Na}_{2} \mathrm{O}$ and $\mathrm{K}_{2} \mathrm{O}$, slightly less $\mathrm{FeO}$ and $\mathrm{CaO}$ and significantly less in $\mathrm{TiO}_{2}$ than 03-127. Garnet megacrysts are in part restitic, so we calculate and compare a pseudosection calculated using the full 03126 composition and one using the bulk composition with the estimated volume of restitic garnet core subtracted (Table 1; Konrad-Schmolke et al., 2008; Tinkham and Ghent, 2005; Zuluaga et
al., 2005). Restitic quartz and uncertainty in measured $\mathrm{SiO}_{2}$ are not likely to be a problem, because both samples contain abundant quartz ribbons (e.g. Indares et al., 2008). 
We included $\mathrm{TiO}_{2}$ in the model system and excluded $\mathrm{MnO}$ and $\mathrm{O}$ (which amounts to

197 eliminating $\mathrm{Fe}^{3+}$ ). Rutile is common in various textural settings including the crystallized melt of

198 the leucosomes and no ilmenite or other iron oxide has been observed in these samples. $\mathrm{TiO}_{2}$

199 is significant in the bulk composition and is present in micas and rutile. MnO is low, was not

200 detected in garnet and is not included in all ferromagnesian phases in the database. There is

201 no evidence of $\mathrm{Fe}^{3+}$ in garnet or any other phase, so it was also excluded. Our model system is, 202 therefore, NCKFMASHT.

203 Our primary goal is to constrain the exhumation path for the North-East Greenland UHP

204 terrane by calculating pseudosections for the metapelites. The $P-T$ path starts from the peak

205 UHP conditions for kyanite eclogites located $1.2 \mathrm{~km}$ WNW of the sampled metapelite outcrop

206 (Gilotti and Ravna, 2002). This estimate of $3.6 \mathrm{GPa}$ and $972^{\circ} \mathrm{C}$ (star on Fig. 4a and all other

207 pseudosections) is based on robust net transfer reactions among solid solution phases in the

208 assemblage garnet, omphacite, kyanite, quartz and/or coesite and phengite and does not 209 depend on knowledge of $\mathrm{Fe}^{3+} / \mathrm{Fe}^{2+}$ (Hacker, 2006). The decompression path from peak UHP

210 conditions is expected to be steep (e.g., Banno et al., 2000; Ernst et al., 2007; Gilotti and

211 McClelland, 2007; Hacker, 2006; Hermann and Rubatto, 2014; Massonne, 2013) but its specific

212 slope and location in $P-T$ space can be determined by comparing observed mineral

213 compositions and assemblages with the models. Likely initial decompression paths (paths 1, 2

214 and 3) are shown in Figure 4. Path 1 with the lowest positive slope is constrained by the

215 absence of biotite in the melt products. Paths 2 and 3 represent the remaining range of likely

216 decompression paths that we will consider. There is no evidence of significant heating upon

217 decompression (e.g. Banno et al., 2000), so paths with a significant negative slope are not

218 favored. We examine the consequences of decompression along the range of likely steep

219 paths (paths 1, 2, and 3) shown for 03-126 H4 on Figure 4a and other pseudosections, and 220 then present constraints on the lower-pressure portion of the $P-T$ path. 
The remaining aspect of the reacting bulk composition that must be evaluated is its $\mathrm{H}$ or

$222 \mathrm{H}_{2} \mathrm{O}$ content. To examine the effect of $\mathrm{H}_{2} \mathrm{O}$-content on the pseudosections, we calculated an

223 isothermal $P-$ mole $\% \mathrm{H}_{2} \mathrm{O}\left(\right.$ moles $\left._{\mathrm{H}}\right)$ section of the phase diagram at $950^{\circ} \mathrm{C}$ for sample $03-126$

224 (Fig. 5; Baldwin et al., 2005, 2007; White et al., 2001). This is the approximate temperature of

225 the initial, near isothermal decompression of REI metapelites. At high $\mathrm{H}_{2} \mathrm{O}$ content (Fig. 5a),

226 decompression from peak conditions would produce melting in the presence of free $\mathrm{H}_{2} \mathrm{O}$ fluid at

227 the estimated peak $P-T$ conditions, above the coesite-quartz transition. Free $\mathrm{H}_{2} \mathrm{O}$ fluid is

228 thought to be unlikely at such high $P-T$ conditions (Hermann and Rubatto, 2014; Rumble 1998;

229 Wallis et al., 2005; White et al., 2001). Textures in the metapelites are more consistent with

230 melting after the coesite to quartz transition; therefore, melting must have taken place below 4

$231 \mathrm{~mole} \% \mathrm{H}_{2} \mathrm{O}$.

There are few constraints on the details of compositions or proportions of minerals in the peak UHP assemblage of REI metapelites, because few remnants of the peak assemblage are preserved. In the next section, we describe calculated mineral modes and compositions for the metapelites at peak conditions; however, only the low Ca cores of garnet megacrysts preserve peak compositions. Rare phengite inclusions in garnet cores may provide further constraints on UHP metamorphic conditions. No relict clinopyroxene is preserved, and all other minerals grew or re-crystallized at lower pressure in the presence of melt. Mole fractions of the end-member components in garnet cores (Table 2) provide the best constraints on peak conditions, including $\mathrm{m}_{\mathrm{H} 2 \mathrm{O}}$ in the metamorphic fluid. To find the least modified garnet megacryst cores, we chose the lowest Ca spots on two mapped garnets, one from sample 03-126 and one from sample 03-127

242 (Fig. 3a). Figure $5 \mathrm{~b}$ shows the $P-m_{\mathrm{H} 2 \mathrm{O}}$ section contoured for $\mathrm{X}_{\mathrm{Grs}}, \mathrm{X}_{\mathrm{Alm}}$ and $\mathrm{X}_{\mathrm{Prp}}$. In the low $m_{\mathrm{H} 2 \mathrm{O}}$ 243 portion of the diagram $\left(m_{\mathrm{H} 2 \mathrm{O}}<4.0\right)$, calculated $\mathrm{X}_{\mathrm{Grs}}, \mathrm{X}_{\mathrm{Prp}}$ and $\mathrm{X}_{\mathrm{Alm}}$ vary dramatically, especially

244 above $2.5 \mathrm{GPa}$. The mean of 13 lowest $\mathrm{Ca}$ garnet analyses in two mapped garnet megacrysts, 245 one from sample 03-126 and one from sample 03-127, yield $X_{G r s}=0.057( \pm 0.006)$,

$246 \mathrm{X}_{\operatorname{Prp}}=0.290( \pm 0.040)$, and $\mathrm{X}_{\mathrm{Alm}}=0.654( \pm 0.039)$ (Table 2). Somewhat fortuitously, the contours at 
those compositions all are relatively steep and converge near 2.0 mole $\% \mathrm{H}_{2} \mathrm{O}$ (which corresponds to 4.0 moles $\mathrm{H}$ ) on the $P-m_{\mathrm{H} 2 \mathrm{O}}$ section of Fig. $5 \mathrm{~b}$. At high pressure and high temperature, phengite has high $\mathrm{Si}$ content and is $\mathrm{TiO}_{2}$ rich (Hermann and Spandler, 2008). Analyzed REI phengite with the highest Si content (3.30 per formula unit) comes from inclusions in the cores of garnet megacrysts. This Si content is consistent with calculated phengite composition at approximately 3.0 GPa and low $\mathrm{H}_{2} \mathrm{O}$ content on the decompression path (Fig. $5 b)$, although the $\mathrm{Si}$ in phengite does not put any further constraint on $\mathrm{H}_{2} \mathrm{O}$ content of the reacting bulk composition. Based on Figure 5, we have calculated the pseudosections at 4 cation\% $\mathrm{H}$ (labeled $\mathrm{H} 4$; equivalent to 2 mole $\% \mathrm{H}_{2} \mathrm{O}$ ).

Figure 4 shows pseudosections at low $\mathrm{H}_{2} \mathrm{O}(\mathrm{H} 4)$ for UHP metapelite sample 03-126, 03126 with the garnet core subtracted and sample 03-127 (Fig. 4a, b, c). Based on Figure 5, any model with up to twice this $\mathrm{H}$-content will yield similar results. The $03-126 \mathrm{H} 4$ pseudosection with the restitic garnet core subtracted (Fig. 4b) is only very slightly different from that using the whole rock bulk composition (Fig. 4a). Some of the phase fields are expanded to slightly higher temperatures, but the diagrams are otherwise remarkably similar. The subtracted volume of restitic garnet core was estimated from the garnet megacryst imaged in Figure $3 \mathrm{~d}$. That garnet has the largest low-Ca core that was mapped and the least evidence of reaction and reequilibration of core garnet with melt during decompression; therefore, we conclude that the isolation of some core garnet did not have a significant effect on the pseudosection results. The pseudosection for sample 03-127 H4 differs only slightly from that of 03-126 H4 (Fig. 4). For example, some of the fields above the solidus that are traversed by the decompression path near $900^{\circ} \mathrm{C}$ from 2.0 to $1.5 \mathrm{GPa}$ contain kyanite on $03-126 \mathrm{H} 4$ (Fig. 4a) and do not contain kyanite on 03-127 H4 (Fig. 4c). One puzzling aspect of the 03-127 H4 pseudosection is the presence of a small field at $1.3-1.6 \mathrm{GPa}$ and $900-1000^{\circ} \mathrm{C}$ in which $\mathrm{Cpx}$ is calculated to be stable ( $<1$ vol.\% Cpx) after $\mathrm{Cpx}$ had been completely consumed at $2.2 \mathrm{GPa}$ along any likely decompression path. This is inconsistent with the lack of any preserved Cpx in the samples. 
273 The sections are otherwise similar, which demonstrates that the position of the phengite

274 dehydration melting reaction is not very sensitive to bulk composition. The low $\mathrm{H}_{2} \mathrm{O}(\mathrm{H} 4)$

275 pseudosection for sample 03-126 (Fig. 4a) is the preferred model for REI metapelites, and we

276 examine the phase assemblages and compositions predicted by that model in detail. We will

277 comment on some changes in the pseudosection that result from subtracting the restitic garnet

278 core.

\section{Phase Equilibria Constraints on the P-T Path}

$281 \quad 5.1$ Peak mineral assemblage

The calculated peak assemblage gives the best estimate of the relative proportions of minerals to be expected in metapelitic rocks at UHP metamorphic conditions and illustrates the

284 effect of small changes in bulk composition. According to the pseudosection (Fig. 4a), sample 03-126 contained volumetric proportions of $26 \%$ clinopyroxene, $\mathrm{X}_{\mathrm{Jd}}=0.76 ; 16 \%$ phengite, $\mathrm{Si}(\mathrm{pfu})=3.35 ; 23 \%$ Grt, $\mathrm{X}_{\mathrm{Grs}}=0.07, \mathrm{X}_{\operatorname{Prp}}=0.40, \mathrm{X}_{\mathrm{Alm}}=0.63 ; 15 \%$ K-feldspar, 3\% kyanite, 15\% coesite and $0.7 \%$ rutile at peak conditions. In contrast, sample $03-127$ had $26 \%$ clinopyroxene, $16 \%$ phengite, $31 \%$ garnet, $5 \%$ K-feldspar, $2 \%$ kyanite, $18 \%$ coesite and $1.3 \%$ rutile by volume. The differences in mineral proportions are consistent with differences in bulk composition: 03127 has more garnet because of its higher $\mathrm{FeO}$, more rutile because of its higher $\mathrm{TiO}_{2}$, lower kyanite because of its lower $\mathrm{Al}_{2} \mathrm{O}_{3}$ and lower alkali feldspar because of its lower $\mathrm{Na}_{2} \mathrm{O}$ and $\mathrm{K}_{2} \mathrm{O}$

292 (Table 1). Although the modeling predicts over 20 vol.\% clinopyroxene (Fig. 6b), no

293 clinopyroxene pseudomorphs, inclusions in garnet or relicts remain. This is puzzling, but some 294 ferro-magnesian mineral must have been present to produce new garnet (rims and matrix) on 295 decompression. Subtracting the garnet core (Fig. 4b) only increases the calculated volume of 296 clinopyroxene. Because the UHP conditions were extreme and melt was present to enhance 297 reaction rates during decompression, the peak assemblage was completely transformed and is 298 only known from the pseudosections. 
5.2 Sequence of HP reactions on the initial decompression path

The earliest effect of decompression from UHP conditions from pseudosection 03-126

$\mathrm{H} 4$ was the transformation of coesite to quartz at approximately 3.0 GPa. With further decompression along any of the likely paths, the dehydration melting reaction of phengite is encountered in the range of 2.7 to $2.2 \mathrm{GPa}$. Any steep, near-isothermal decompression path will cross the coesite-quartz reaction before the phengite dehydration melting reaction (Fig. 4a,

$306 \mathrm{~b}, \mathrm{c})$. For the $P-T$ path to cross the phengite dehydration melting reaction at pressures above 3.0 GPa, the rocks would have to experience substantial heating upon decompression, for which there is no evidence.

Lang and Gilotti (2007) initially interpreted the textures of the anatectic metapelites to indicate that phengite dehydration melting took place above the coesite-quartz transition, but we have re-examined the textures in light of the new modeling results. Although no coesite has

312 been found, garnet megacrysts contain polycrystalline quartz inclusions surrounded by radial fractures. Matrix leucosomes and polyphase inclusions in garnet megacrysts show abundant

314 evidence of partial melting (Lang and Gilotti, 2007; Fig. 2), with evidence that the melt 315 penetrated the garnet megacrysts to produce moat-like rims of quartz, plagioclase and alkali 316 feldspar around many of the polycrystalline quartz inclusions (Fig. 2c, d). In some cases, the 317 melt (now quartz plus plagioclase, K-feldspar $\pm \mathrm{Ky} \pm \mathrm{Rt}$ ) appears to have penetrated the 318 surrounding garnet along fractures (Fig. 2c, d). These textures suggest that fractures in garnet 319 and weaknesses between former coesite inclusions (now quartz) and surrounding garnet were 320 open to the melt when it formed, consistent with the phase relations along all likely $P-T$ paths in 321 Figure 4. Ragozin and others (2009) also concluded that partial melting of UHP rocks from the 322 Kumdy Kol region of the Kokchetav massif occurred during decompression, probably in the 323 quartz stability field. 
5.3 Dehydration melting of phengite and the disappearance of clinopyroxene

The first reaction encountered by the metapelites below the coesite $=$ quartz transition is the dehydration melting reaction of phengite:

$$
\mathrm{Cpx}+\mathrm{Ph}+\mathrm{Grt}+\mathrm{Kfs}+\mathrm{Ky}+\mathrm{Qz}+\mathrm{Rt}=\mathrm{Cpx}+\mathrm{Grt}+\mathrm{Liq}+\mathrm{Kfs}+\mathrm{Ky}+\mathrm{Qz}+\mathrm{Rt}
$$

at pressure and temperature that depend on the exact $P-T$ path (Fig. 4a). At this reaction, all of the phengite is consumed over a very narrow pressure range along any of the likely $P-T$ paths (Fig. 6a). The calculated range of phengite composition from peak UHP conditions to phengite dehydration melting is 3.35 to $3.25 \mathrm{Si}$ (Fig. 6a). The Si-content of phengite in the samples ranges from 3.12 to 3.30 , consistent with some phengite relicts (especially phengite included in garnet) having been preserved from UHP conditions. Matrix phengite $(\mathrm{Si}=3.1$ to 3.25$)$ apparently formed upon cooling at approximately $1.3 \mathrm{GPa}$ at or just above the solidus, again consistent with the pseudosection (Fig. 6a). According to Hermann and Green (2001) and changes in the calculated mode for sample 03-126, the net phengite dehydration melting reaction is

$$
\mathrm{Cpx}+\mathrm{Ph}+\mathrm{Qz}=\mathrm{Grt}+\mathrm{Ky}+\mathrm{Kfs}+\mathrm{Liq}
$$

In the REI samples, garnet remained as restite and new garnet grew after the phengite dehydration melting reaction was crossed. Minor phengite remains as inclusions in garnet; kyanite, K-feldspar and quartz remain in the matrix and are affected by melting and recrystallization. This reaction defines the solidus, and 9 to 13 volume $\%$ of melt forms as a result of phengite dehydration melting over a very narrow range of $P-T$ conditions, depending on the exact path (Fig. 6a).

The pseudosection shows that clinopyroxene in sample $03-126$ is consumed over a range of pressure, determined by the precise $P-T$ path (Fig. 6b). Initial consumption at the phengite dehydration melting reaction is abrupt (with up to half of the clinopyroxene being consumed in a 0.02 GPa pressure range), while complete consumption is gradual over a pressure range spanning approximately $0.2 \mathrm{GPa}$. The calculated composition of clinopyroxene 
as it is consumed changes from $\mathrm{X}_{\mathrm{Jd}}=0.7$ to $\mathrm{X}_{\mathrm{Jd}}=0.4$ (Fig. $6 \mathrm{~b}$ ). Because felsic melt was present, the clinopyroxene break-down reaction must have been rapid and complete, leaving no relicts or textural evidence in the samples.

\subsection{Garnet rim growth and changes in garnet composition}

The volume of garnet does not change along the decompression path from the metamorphic peak to the phengite dehydration melting reaction, and calculated $\mathrm{X}_{\mathrm{Grs}}$ in garnet remains nearly constant at 0.06 to 0.07 (Fig. 6c). Mole fractions of all garnet components are constant during decompression along all the likely $P-T$ paths from peak conditions to the dehydration melting curve. It is therefore not surprising that compositions in the cores of relict UHP garnets that have not interacted with melt are relatively homogeneous (Fig. 3). Beginning at the phengite dehydration melting curve and over the same pressure range where clinopyroxene is consumed ( 2.4 to $2.2 \mathrm{GPa}$ ), garnet increases in volume from $22 \%$ to a maximum of $27 \%$ with a concomitant increase in grossular content from 0.06 to 0.13 (Fig. 6c). Omphacitic clinopyroxene is consumed as garnet grows in the assemblage clinopyroxenegarnet-liquid-K-feldspar-kyanite-quartz-rutile by a continuous reaction. Auzanneau and others (2006) observed a similar increase in modal proportion and grossular content of garnet in their experiments in the pressure range of 2.5 to $2.3 \mathrm{GPa}$.

Garnet shows a dramatic increase in grossular content toward its rims and in regions that interacted with (or crystallized from) melt (Fig. 3a, d). The low-grossular core of the garnet in Figure $3 a$ is interpreted to be restitic. High-grossular garnet at the rims and around inclusions shows abundant evidence of interaction with melt and, thus, has grown or recrystallized in equilibrium with melt on the decompression path. Coincident growth of garnet and increase in grossular content, which is necessary to explain the growth of the high grossular garnet rims, is successfully modeled by the pseudosection (Fig. 6c; see also Auzanneau et al., 2006). The region above the solidus at which garnet reaches its maximum volume and maximum grossular 
content (highlighted in Fig. 6c) puts additional limits on the P-T path (Fig. 4a, 6c). The steep part of the decompression path must pass through the high grossular region in which garnet grows. This eliminates paths as shallow as path 1, and restricts the actual path to the region between path $1^{*}$ and path 3 (Fig. $4 \mathrm{a}, 6 \mathrm{c}$ and $7 \mathrm{a}$ ). Clinopyroxene must have been the calcium source for the growing garnet rims (c.f. Massonne, 2009). The REI metapelites are one of several examples where the most grossular-rich garnet is not formed at highest pressure (c.f., Menold et al., 2009; Storm and Spear, 2005). Small garnet crystals in the matrix have high grossular in their cores similar to the rim garnet, and like the megacryst rims are interpreted to have grown in equilibrium with the melt. The isochemical $P-T$ section shows a maximum $\mathrm{X}_{\mathrm{Grs}}$ of 0.13 , whereas the measured $X_{\text {Grs }}$ in garnet rims in $03-126$ is 0.17 to 0.18 and in $03-127$ is up to 0.20. The pseudosection for sample 03-127, although unsatisfactory in other ways, shows a maximum $\mathrm{X}_{\mathrm{Grs}}$ of $0.17-0.18$ and more closely matches the observed garnet rim composition. The discrepancy between the maximum measured and calculated $\mathrm{X}_{\mathrm{Grs}}$ is explained in part by fact that the cores of garnet megacrysts were restitic and not part of the reacting bulk composition. Contours on the pseudosection calculated from the bulk composition of 03-126 with garnet core subtracted (Fig. 4b) show a similar increase in garnet volume with decompression to a maximum just below the clinopyroxene-out reaction. They also show an increase in $\mathrm{X}_{\text {Grs }}$ to a maximum of 0.16 , which is a better match to measured garnet rim values. If the rocks continue along any of the steep decompression paths, the grossular content decreases and garnet is consumed between 2.0 and $1.5 \mathrm{GPa}$. If the $P-T$ path flattens out below 2.0 GPa, garnet consumption and decrease in $\mathrm{X}_{\text {Grs }}$ will slow, but substantial garnet will still be consumed as any likely path approaches the solidus. However, there is little evidence of garnet consumption or retrograde effects suggesting that the liquid quenched rapidly or melt was lost (e.g. White et al., 2001).

Changes in almandine component are less dramatic and antithetical to the grossular component. In the pseudosection (Fig. 6d), almandine content remains approximately constant 

417 path.

418

419

420

421

422

423

424

425

426

427

at 63 mole\% along the steep part of the decompression paths until they cross the phengite dehydration melting curve. From there the almandine content decreases to a minimum of approximately 54 mole\% in the same region where $\mathrm{X}_{\text {Grs }}$ reaches its maximum. On the Fe X-ray map (Fig. 3b), the low-Grs garnet core has high Alm content, which drops off coincident with the high-Grs garnet rim, and there is a narrow, but distinct, high-Alm rim along parts of the garnet margin (Fig. 3b, note especially the outermost high Alm garnet margin near the red color bar on the right side of the garnet map). Pyrope content increases gradually from its value at peak conditions along all of the steep decompression paths (Fig. 6d). On the Mg X-ray map (Fig. 3c), the highest pyrope coincides with the low grossular core with no detectable increase toward the garnet rim, but at the very outer rim pyrope drops off and remains low. The measured values of $\mathrm{X}_{\mathrm{Alm}}, \mathrm{X}_{\mathrm{Grs}}$ and $\mathrm{X}_{\mathrm{Prp}}$ are in the same range, but do not exactly match the calculated values. In the mid-pressure range (2.2 to $1.5 \mathrm{GPa}$ ), compositional contours for all garnet components are nearly parallel and widely spaced, and the components have different sensitivity to diffusion and re-equilibration with melt, so garnet composition does not provide tight limits on this part of the

\subsection{Additional Constraints and Choice of the Preferred $P-T$ path}

The coincidence of abrupt garnet growth and increase in the grossular content from 2.22.4 GPa at $920-1030^{\circ} \mathrm{C}$ provides the best constraint on possible decompression paths from the estimated peak conditions of $972^{\circ} \mathrm{C}$ at $3.6 \mathrm{GPa}$ (Paths $1^{*}, 2$, and 3 of Fig. $6 \mathrm{c}, 7 \mathrm{a}$ ). In the middle pressure range from 2.2 to $1.5 \mathrm{GPa}$, in the field of garnet, liquid, plagioclase, K-feldspar, kyanite, quartz, rutile, there are many gradual changes in the composition and proportion of garnet, plagioclase, K-feldspar and liquid. We will review calculated and observed phase changes in this assemblage, but they do not provide good limits on the $P-T$ path; therefore, we focus on the low-pressure, cooling part of the path. 

rocks begin cooling and the $P-T$ path flattens out, garnet volume isopleths (Fig. 6c) are parallel to the path and less garnet will be consumed. As the $P-T$ path approaches the solidus and crosses the steep isopleths in the garnet, liquid, biotite, plagioclase, K-feldspar, kyanite, quartz, 432 rutile field, garnet consumption will be significant. If the path crosses that field at relatively high 433 pressure, few garnet isopleths will be crossed and less garnet will be consumed.

The mineral assemblage and compositions most likely to be preserved in partially melted rocks are those that form as the rocks cross the solidus on the cooling path (Indares et al., 2008). The lack of retrograde textures and minerals in rocks that have crystallized after partial melting is attributed to the sluggishness of reactions in the absence of melt or fluid (e.g. Guiraud et al., 2001; Pattison and Begin, 1994; White and Powell, 2002). Crystallized melt in the REI metapelites is fine-grained and is surrounded by a matrix of antiperthitic feldspar and quartz; it contains scattered grains of biotite, phengite, kyanite, minor rutile and small garnet crystals. Biotite, phengite, and kyanite are commonly in contact with one another. Some areas of crystallized melt lack kyanite or phengite, but the most common melt crystallization assemblage is phengite, garnet, biotite, plagioclase, K-feldspar, kyanite, quartz and rutile. Some phengite, which is present in the matrix and in the leucosomes, appears to have crystallized at or just above the solidus on the cooling path as the melt crystallized, which is consistent with the pseudosection and constrains the $P-T$ path (Fig. 6a, 7). The majority of the phengite has

$447 \mathrm{Si}<3.25$ that agrees with calculated values for late, low pressure phengite formed at or near the 448 solidus (Fig. 6a). Crystallized melt layers and lenses contain small amounts of kyanite, but no 449 sillimanite. Minor rutile is observed in the matrix, but the samples contain no ilmenite.

450 Therefore, the lowest pressure-temperature assemblage formed above the kyanite to sillimanite 451 and rutile to ilmenite transitions. The $P-T$ path must have crossed the solidus and entered the 452 phengite, garnet, biotite, plagioclase, K-feldspar, quartz, rutile \pm kyanite field at approximately $453800^{\circ} \mathrm{C}$ between 1.1 and $1.3 \mathrm{GPa}$ (Fig. 7). Once the solidus is crossed, reactions slow 
dramatically, but it is likely that the $P-T$ path flattens out at a pressure of approximately $1.2 \mathrm{GPa}$ in the phengite, garnet, biotite, two feldspar, kyanite, quartz, rutile field.

We are unable to determine the slope of the high pressure $P-T$ path or the point at which it changes from near isothermal to near isobaric. In the absence of any evidence of heating on decompression, we have chosen a steep decompression path with a slight positive slope that begins to level off at approximately $925^{\circ} \mathrm{C}$ and $1.5 \mathrm{GPa}$ and becomes isobaric at $\sim 1.2$ GPa, while cooling to at least $600^{\circ} \mathrm{C}$ (Fig. 7). The preferred $P-T$ path goes through the center of the area below the clinopyroxene-out reaction, where garnet grows to a maximum grossular content, and changes slope to be parallel to the garnet isopleths (Fig. 8). It crosses the solidus below 1.3 GPa to enter the phengite, garnet, biotite, two feldspar, kyanite, quartz, rutile field, which matches the most common matrix assemblage that includes crystallized melt and garnet rims. A path that levels off at higher pressure would consume less garnet, but would not contain kyanite in the immediate subsolidus assemblage.

\subsection{Feldspar behavior on the exhumation path}

Nearly all fields on the pseudosections contain one or two feldspars (Fig. 4a, c). The models predict that the metapelites consisted of 16 vol.\% K-rich (>90 mole\% sanidine) alkali feldspar (Fig. 8a), and plagioclase was not stable at UHP conditions. Upon decompression the alkali feldspar becomes more albite-rich as clinopyroxene is consumed (Fig. 6a, b; 8a). The volume of alkali feldspar increases significantly (from 22 to 44 vol.\%), until clinopyroxene disappears at approximately $2.25 \mathrm{GPa}$, where plagioclase joins the assemblage (Fig. 8a). As the $P-T$ path enters the liquid plus two feldspar field, the volume of alkali feldspar decreases significantly (Fig. 8a), while plagioclase grows, increasing in volume to $30 \%$ over a narrow pressure range as the $P-T$ path flattens. Near the solidus, much of the alkali feldspar is consumed (along with liquid) until only about 15 vol.\% alkali feldspar remains, while plagioclase $\left(\mathrm{An}_{28}\right)$ increases in volume to $35 \%$ (Fig. 8a). Below the solidus, plagioclase composition is 
constant to at least $600^{\circ} \mathrm{C}$ (Fig. 8c). In the pseudosection, plagioclase and alkali feldspar coexist with liquid above the solidus for this bulk composition. While the proportion of plagioclase (Fig. 8a) increases along the decompression path, the proportion of alkali feldspar decreases. The volume of liquid initially increases and then decreases as the $P-T$ path approaches the solidus in the down-temperature direction (Fig. 6a). As the $P-T$ path levels off, the pseudosection predicts that alkali feldspar ( 27 vol.\%) has a composition of $\mathrm{X}_{\mathrm{Ab}}=0.30$, $\mathrm{X}_{\mathrm{An}}=0.02$ and $\mathrm{X}_{\mathrm{Or}}=0.70$ (Fig. 8a, b), while the coexisting plagioclase ( 30 vol.\%) has a composition of $\mathrm{X}_{\mathrm{Ab}}=0.65, \mathrm{X}_{\mathrm{An}}=0.27$ and $\mathrm{X}_{\mathrm{Or}}=0.08$ (Fig. $8 \mathrm{a}, \mathrm{c}$ ).

The REI metapelites contain two different feldspars in a variety of different textural settings. Feldspars occur in polyphase inclusions in garnet, as separate plagioclase and alkali feldspar grains in moats around quartz inclusions in garnet megacrysts; as host and lamellae in antiperthite, which is abundant in the leucocratic rock matrix; and plagioclase occurs with biotite as pseudomorphs after phengite in the matrix. In 03-126, analyzed plagioclase ranges from $\mathrm{X}_{\mathrm{An}}=0.115$ to 0.385 with a mean of $0.190, \mathrm{X}_{\mathrm{Ab}}=0.601$ to 0.845 with a mean of 0.792 , and $\mathrm{X}_{\mathrm{Or}}=$ 0.011 to 0.029 with a mean of 0.018 (29 analyses). In 03-127, plagioclase is $\mathrm{X}_{\mathrm{An}}=0.177$ to 0.327 with a mean of $0.239, \mathrm{X}_{\mathrm{Ab}}=0.658$ to 0.799 with a mean of 0.743 , and $\mathrm{X}_{\mathrm{Or}}=0.009$ to 0.035 with a mean of 0.018 (31 analyses). Alkali feldspar also varies in composition: in 03-126, $\mathrm{X}_{\mathrm{Or}}=0.788$ to 0.926 with a mean of $0.871, \mathrm{X}_{\mathrm{Ab}}$ ranges from 0.074 to 0.191 with a mean of 0.126 and $\mathrm{X}_{\mathrm{An}}$ ranges from 0.000 to 0.022 with a mean of 0.004 (22 analyses), while in $03-127$, alkali feldspar is $\mathrm{X}_{\mathrm{Or}}=0.833$ to 0.937 with a mean of $0.881, \mathrm{X}_{\mathrm{Ab}}$ is 0.061 to 0.167 with a mean of 0.117 and $\mathrm{X}_{\mathrm{An}}$ ranges from 0.000 to 0.004 with a mean of 0.001 (17 analyses).

Although Lang and Gilotti (2007) inferred that antiperthitic feldspar formed upon crystallization of the melt, the pseudosection indicates that antiperthite formed in equilibrium with melt above the solidus (Fig. 8a). In 03-126, the proportions of alkali and plagioclase feldspar in antiperthite, estimated by image analysis of an X-ray map, range from 58 vol.\% plagioclase and 42 vol.\% alkali feldspar to 45 vol.\% plagioclase and 54 vol.\% alkali feldspar. 
Average measured compositions of the two coexisting feldspars in antiperthite of 03-126 are plagioclase $\left(\mathrm{X}_{\mathrm{Ab}}=0.826, \mathrm{X}_{\mathrm{An}}=0.157, \mathrm{X}_{\mathrm{Or}}=0.017\right)$ and alkali feldspar $\left(\mathrm{X}_{\mathrm{Or}}=0.897, \mathrm{X}_{\mathrm{Ab}}=0.101\right.$, $\left.\mathrm{X}_{\mathrm{An}}=0.003\right)$. The calculated proportions of plagioclase and alkali feldspar at the bend in the $P-T$ path are $53 \%$ plagioclase and $47 \%$ alkali feldspar; at the solidus, the calculated proportions are $64 \%$ plagioclase and $36 \%$ alkali feldspar. This suggests that the relative proportions of plagioclase and alkali feldspar were fixed early in the melt plus two feldspar field as the $P-T$ path began to level off. Note that the total volume\% of feldspar remains at 50 to $55 \%$ across the part of the two feldspar plus liquid region traversed by the $P-T$ path (Fig. 8a).

The measured compositions of coexisting feldspars in antiperthite are different than those predicted by the pseudosection for conditions above $600^{\circ} \mathrm{C}$, suggesting that the feldspars continued to re-equilibrate to lower temperatures (Fig. 8b, c). The measured compositions of plagioclase and alkali feldspar in the antiperthite of $03-126$ define a point near $550^{\circ} \mathrm{C}$ and 1.25 GPa, well along the isobaric cooling portion of the $P-T$ path. Other analyzed feldspars in 03126 and 03-127 are generally consistent with final equilibration at even lower temperature.

\subsection{Calculated melt characteristics}

The estimated $P-T$ decompression path for REI metapelites is above the solidus for a range of conditions between 2.5 and $1.2 \mathrm{GPa}$. The maximum calculated volume percent of liquid along that path is approximately 12 vol.\% (Fig. 6a), which is roughly consistent with the volume of leucosome in the partially melted samples. $\mathrm{H}_{2} \mathrm{O}$, albite, K-feldspar and quartz are the only significant components in the calculated liquid. In the region traversed by the estimated $P$ $T$ path, $\mathrm{X}_{\mathrm{H} 2 \mathrm{O}}{ }^{\text {Liq }}$ ranges from 0.52 to $0.60, \mathrm{X}_{\mathrm{Ab}}{ }^{\text {Liq }}$ is approximately $0.2, \mathrm{X}_{\mathrm{Kfs}}{ }^{\text {Liq }}$ ranges from 0.1 to 0.15 and $\mathrm{X}_{\mathrm{Qz}}{ }_{\mathrm{Liq}}^{\mathrm{iq}}$ is approximately 0.1 . Melt composition and proportion can be calculated at any point above the solidus with the Theriak program. Melt compositions were calculated for samples 03-126 and 03-127 just below the intersection of the $P-T$ path with the solidus (at 2.3 GPa, $945^{\circ} \mathrm{C}$, Liquid A), at the bend in the $P-T$ path (at $1.55 \mathrm{GPa}, 900^{\circ} \mathrm{C}$, Liquid $\mathrm{B}$ ); and just 
532 above the intersection of the $P-T$ path with the solidus in the down-temperature direction (at $5331.25 \mathrm{GPa}, 800^{\circ} \mathrm{C}$, Liquid $\mathrm{C}$ ). Calculated melt compositions are generally granitic with alkaline 534 and weakly peraluminous compositions (Table 3). Initial melts (Liq A) calculated near the high 535 pressure intersection with the solidus are sodic, whereas later melts (Liq B and C) are potassic 536 (Table 3).

5.8 $P T-n$ and $P T-X$ diagrams summarize changes along the $P-T$ path Calculated mineral modes and mineral compositions for the REI metapelites are shown along a two segment approximation of the $P-T$ decompression path (Fig. 9) in Figure 10. Because the $P-T$ path has a nearly isothermal segment followed by a nearly isobaric segment, 542 the scales of Figure 10 are split at the bend $\left(930^{\circ} \mathrm{C}, 1.3 \mathrm{GPa}\right)$. The $P$ and $T$ scales are reversed so that the diagrams follow the estimated $P-T$ path from peak UHP conditions at the left to low $P$, low $T$ conditions at the right. The calculated number of moles of each phase of interest is shown over the range in $P$ or $T$ (Fig. 10a) and mole fractions of important components in solution phases are plotted relative to $P$ or $T$ in Figure $10 \mathrm{~b}$. These $P T-n$ and $P T-X$ modal assemblage diagrams visually summarize the mineral reactions in the metapelites and changes in mineral compositions along the entire exhumation path.

At PT1, coesite is replaced by quartz and from 2.4 to $2.2 \mathrm{GPa}$ (PT2 to PT4, Fig. 10a, b), several dramatic changes in the metamorphic assemblage take place. Phengite breaks down completely by its dehydration melting reaction, which consumes omphacitic clinopyroxene and

552 quartz and produces liquid, K-feldspar, kyanite and garnet at approximately 2.43 GPa (PT2).

553 Below the phengite dehydration melting reaction between $2.42 \mathrm{GPa}$ and 2.30 GPa (PT2 and

554 PT3 on Fig. 10), significant clinopyroxene and quartz are consumed along with some kyanite 555 while K-feldspar grows. The jadeite content of clinopyroxene decreases, while $\mathrm{X}_{\text {san }}{ }^{\mathrm{Kfs}}$ decreases 556 and $X_{a b}{ }^{K f s}$ increases; $X_{a l m}{ }^{\text {Grt }}$ decreases slightly and $X_{\text {grs }}{ }^{\text {Grt }}$ increases slightly (Fig. 10b). The 557 reaction between PT2 and PT3 is essentially Jd (in Cpx) + Qtz = Ab (in Kfs). At approximately 
2.3 GPa (PT3), plagioclase becomes stable and grows along with new garnet at the expense of clinopyroxene, kyanite and K-feldspar over the pressure range of 2.3 to $2.2 \mathrm{GPa}$ (PT3 to PT4 on Fig. 10a) until all the clinopyroxene is consumed at PT4. Over the pressure range from PT2 to PT4, the grossular content of garnet increases dramatically. Although the absolute change in $\mathrm{X}_{\mathrm{grs}}$ is small, it amounts to almost a $100 \%$ relative increase (Fig. 10b). The calculated increase in grossular content accompanied by garnet growth is observed in the dramatic increase in Cacontent at the rims of garnet megacrysts in all REI metapelites (Fig. 3a, d). The maximum amount of liquid was approximately 12 vol. \% at the bend in the $P-T$ path (PT5).

The changes in the calculated $P T-n$ and $P T-X$ diagrams (Fig. 10a, b) between $855^{\circ} \mathrm{C}$ and $800^{\circ} \mathrm{C}$ (PT6 and PT7, the solidus) are the consequence of crystallization of the liquid and growth of biotite. The PT-n section (Fig. 10a) indicates significant consumption of garnet and K-feldspar and production of biotite, kyanite and plagioclase as the liquid crystallizes between PT6 and PT7. The decrease in $\mathrm{n}_{\text {Grt }}$ from PT6 to PT7 is approximately $33 \%$. There is no evidence of garnet consumption in the thin sections or garnet zoning maps (Fig. $2 b$ and 3), in particular, all of the fine garnet growth textures that are preserved in the Ca maps of garnet rims (Fig. 3a, d) would have been consumed if $33 \%$ of the garnet was lost. At PT7, phengite again becomes stable and grows at the expense of liquid, kyanite and K-feldspar (Fig 10a, Fig. 6a). This is consistent with the observation that some phengite, which is partially converted to biotite+plagioclase pseudomorphs, is present in the matrix. Only slight changes in garnet, biotite and feldspar compositions are predicted between PT7 and PT8 (Fig. 10a,b).

\section{Discussion}

Rare metapelites in the North-East Greenland UHP terrane exhibit partial melting during decompression from high temperature $\left(970^{\circ} \mathrm{C}\right)$ and high pressure (3.6 GPa). The amount of melt produced is limited by the amount of phengite present in the rocks at UHP conditions, 
583

584 585

586

587

588

589

590

591

592

593

594

595

596

597

598

599

600

601

602

603

604

605

606

607

608

calculated here to be $16 \%$ by volume. The timing of melting, the possibility of melt loss, and the implications of phengite dehydration melting for UHP terranes in general is discussed below.

\subsection{The timing of melting in the North-East Greenland UHP terrane}

Examination of isochemical sections has made it possible to establish that dehydration melting of phengite in the metapelites on Rabbit Ears Island began on the steep decompression path after the rocks crossed the coesite to quartz reaction. U-Pb ion probe dating of coesitebearing zircon domains in eclogites and an orthogneiss, identified in cathodoluminescence images, shows that UHP metamorphism occurred between 365-350 Ma (Gilotti et al., 2014; McClelland et al., 2006). The largest leucosome in the metapelites (Fig. 2a) did not yield any Caledonian zircon (W.C. McClelland, personal communication 2014); therefore, these melts could not be dated directly. However, two granitic pegmatites (one garnet-bearing) associated with large, coesite-bearing, kyanite-eclogite boudins yield ${ }^{206} \mathrm{~Pb} /{ }^{238} \mathrm{U}$ sensitive high-resolution ion microprobe ages of $437 \pm 5$ Ma (M.S.W.D. = 1.1 from 8 analyses) and $437 \pm 2$ Ma (M.S.W.D. = 1.8 from 8 analyses), and are the oldest zircon ages retrieved from leucosomes on REI (Gilotti and McClelland, 2007). These granitic bodies were probably derived from phengite dehydration melting of the surrounding orthogneiss, where phengite would have been a stable phase at UHP conditions (e.g. Schmidt et al. 2004, Massonne, 2009). We infer that the fluid absent phengite dehydration melting of the metapelites at approximately $940^{\circ} \mathrm{C}$ and $2.5 \mathrm{GPa}$ (Fig. 9) must be at least $347 \mathrm{Ma}$, and that the decompression from 3.6 to $2.5 \mathrm{GPa}$ was quite rapid (McClelland and Lapen, 2013).

Exhumation slowed where the $P-T$ path for the metapelites bends and becomes isobaric at approximately $1.3 \mathrm{GPa}$, crossing the solidus at $800^{\circ} \mathrm{C}$ and $1.2 \mathrm{GPa}$ (Fig. 9). The solidus was probably intersected just before $330 \mathrm{Ma}$, based on the Ti-in-zircon temperatures retrieved from zircon domains in small leucocratic intrusions in the host gneisses (Gilotti et al., 2014). Many of these leucosomes are hornblende-bearing and are interpreted to represent melting caused by 
609

610

611

612

613

614

615

616

617

618

619

620

621

622

623

624

625

626

627

628

629

630

631

632

633

634

the introduction of a hydrous fluid to the gneisses (Gilotti et al., 2014), a process not seen in the metapelites. A final gasp of pegmatite activity, seen in large pegmatite dikes that cross cut the gneissosity of the UHP rocks, is recorded at $320 \mathrm{Ma}$ down to $550^{\circ} \mathrm{C}$ (Gilotti et al., 2014). After this stage, the UHP terrane may have stalled at the lower crust (e.g. Walsh and Hacker, 2004) and few subsequent changes at lower temperatures are seen in the metapelites.

\subsection{Lack of retrograde effects and the possibility of melt loss}

The two metapelite samples described here show little evidence of low grade retrogression. In particular, high Ca rims on garnet preserve intricate textures that mimic the shapes and zonation of small garnets in the crystallized melt patches (Fig. 3a, d, e). Garnet megacryst rims are made up of tiny high Ca garnet nuclei that coalesce into a continuous rim (Fig. 3). Megacryst rims and small matrix garnets both preserve high $\mathrm{Ca}$ interiors and lower $\mathrm{Ca}$ rims that are predicted by growth on the decompression path by the consumption of clinopyroxene (at approximately $2.2 \mathrm{GPa}$ ). The pseudosections (Fig. 6c) predict significant garnet consumption (from 23 to 17 vol.\%) as the cooling path approaches the solidus at 850 to $800^{\circ} \mathrm{C}$ and $1.2 \mathrm{GPa}$. Consumption of that much garnet would have completely obliterated the high $\mathrm{Ca}$ garnet rim and the delicate textures that are shown in Figure $3 \mathrm{~d}$ and e. The common lack of extensive retrogression in partially melted granulites and eclogites may result from loss of melt (and the $\mathrm{H}_{2} \mathrm{O}$ it contains) from the rock (Brown, 2007; White and Powell, 2002; White et al., 2001). This leaves a relatively dry residuum and a small amount of leucosome with a small proportion of hydrous minerals (biotite and phengite) that formed just above the solidus, similar to observations from the REI metapelites.

The maximum calculated volume of melt in 03-126 is 12 volume\%, produced at the bend in the exhumation path (Fig. 9). Rosenberg and Handy (2005) suggest that melt loss is common in deformed rocks with as little as 7 mole\% melt, so some melt loss from the REI metapelites is expected. Melt loss may have been accomplished by wholesale migration from 
635

636

637

638

639

640

641

642

643

644

645

646

647

648

649

650

651

652

653

654

655

656

657

658 659 (Kotková et al., 2011) is promising in this regard. amphibole-bearing leucosomes.

\subsection{Implications for partial melting of UHP terranes}

the rock volume or segregation of melt into layers and lenses (White and Powell, 2002) that are isolated, especially from garnet megacrysts. Aside from the one large $(15 \mathrm{~cm}$ thick) leucosome in Fig. 2a, individual leucosome layers are $>2 \mathrm{~cm}$ thick; most of the REI metapelites still contain approximately $10 \%$ leucosome, consistent with only small amounts of melt loss from the immediate outcrop. The metapelitic bulk composition of the large, homogenized samples also suggests that most of the melt segregated into leucosomes that still reside in the paragneiss. Water produced by crystallization of the melts at $800^{\circ} \mathrm{C}$ was probably expelled into the orthogneisses where it contributed to lower temperature, wet melting that produced the later

Partial melting is sometimes invoked as the trigger for exhumation of UHP terranes (e.g. Gerya et al., 2008; Labrousse et al., 2011; Whitney et al., 2009), but in order for this mechanism to work, melting must start at peak pressure. Phengite is the most common and volumetrically important hydrous mineral at UHP conditions (Hermann and Rubatto, 2014). It is stable over a very large region of $P-T$ space to temperatures $>900^{\circ} \mathrm{C}$ in the coesite field in common crustal bulk compositions (Hermann and Green, 2001; Massonne, 2009; Schmidt et al. 2004).

Therefore, phengite dehydration melting on a prograde path can only occur at temperatures above $900^{\circ} \mathrm{C}$ at UHP. The diamondiferous, quartzofeldspathic saidenbachite from the Erzgebirge and the kumdykolite from the Kokchetav Massif are strong candidates for melt products of metasedimentary rocks at UHP on a prograde (increasing T) path (e.g. Massonne and Fockenberg, 2012). Other candidates include high- and ultrahigh-temperature (HT and UHT) granulites (e.g. Kotková and Harley, 2010), whose UHP history may have been destroyed by melting. Indeed, the discovery of diamonds in typical granulites from the Bohemian massif 
A phengite melting curve is more likely to be crossed on the isothermal decompression

661

662

663

664

665

666

667

668

669

670

671

672

673

674

675

676

677

678

679

680

681

682

683

684

685

segment of the $P-T$ path after exhumation has begun-as is the case for the North-East

Greenland example and diamond-bearing metapelites from the Rhodope mountains, Greece (Mposkos and Krohe, 2006). Many diamond-bearing gneisses with peak $T$ estimates above $800^{\circ} \mathrm{C}$ have potentially experienced phengite dehydration melting on an isothermal decompression path. It may be that peak $T$ is underestimated because of diffusion in garnet and melting of the highest Si-in-phengite grains. For example, the diamond-bearing paragneisses on Fjortoft, Norway (Dobrzhinetskaya et al., 1995) have clearly melted (see Fig. $5 a$ in Gilotti, 2013), yet the highest temperature is estimated from nearby eclogites at $820^{\circ} \mathrm{C}$ (Terry et al. 2000). P-T paths that heat during decompression, such as those for the DabieSulu UHP terrane, China (Zheng et al., 2011), will also cross the phengite dehydration melting curve. For example, Liu et al. (2013) used polyphase inclusions in garnet to infer incongruent phengite melting at $1.5-2.0 \mathrm{GPa}$ and $750-800^{\circ} \mathrm{C}$ after significant decompression from $3.6 \mathrm{GPa}$ and heating from $650^{\circ} \mathrm{C}$. These examples show that phengite dehydration melting is not a general trigger for exhumation, except in the cases of very hot UHP terranes.

\section{Conclusions}

We have constructed a $P-T$ path for partially melted metapelites from the North-East Greenland UHP terrane based on comparison of pseudosections with observed mineral assemblages, chemistry and preserved textures. This is the first quantitative estimate of the exhumation path for the UHP terrane. The $P-T$ path consists of a rapid, near-isothermal segment from peak UHP conditions at $970^{\circ} \mathrm{C}$ and $3.6 \mathrm{GPa}$ to $930^{\circ} \mathrm{C}$ and $1.3 \mathrm{GPa}$ followed by a slow, near-isobaric segment from $930^{\circ} \mathrm{C}$ and $1.3 \mathrm{GPa}$ to $640^{\circ} \mathrm{C}$ and $1.2 \mathrm{GPa}$. A pseudosection with low $\mathrm{H}_{2} \mathrm{O}$ predicts dramatic changes in phase relations and mineral composition from the UHP assemblage of coesite, omphacite, garnet, K-feldspar, phengite, kyanite and rutile to the inception of melting between 2.4 and $2.2 \mathrm{GPa}$. In particular, fluid-absent dehydration melting of 
686

687

688

phengite, the appearance of plagioclase (the second feldspar) and breakdown of omphacite produces melt, plagioclase and high-Ca garnet rims. The modeling also predicts maximum garnet growth at $P-T$ conditions just below the final clinopyroxene breakdown reaction, coincident with maximum $\mathrm{X}_{\text {grs }}$. The calculated assemblage between 2.2 and $1.4 \mathrm{GPa}$ is comprised of quartz, K-feldspar, plagioclase, garnet, liquid, rutile and kyanite. The mode of Kfeldspar decreases with decreasing $P$ and $T$ as the mode of plagioclase increases; plagioclase becomes more anorthite-rich and K-feldspar becomes more sanidine rich. Similar relations are observed in common antiperthitic feldspars in the rocks. Between $855^{\circ} \mathrm{C}$ and $800^{\circ} \mathrm{C}$, liquid crystallizes to form biotite, plagioclase, quartz, and kyanite. The model predicts that garnet is consumed in this temperature range (Fig. 6c); however, consumption of garnet is not observed and the volume\% of biotite is much lower than predicted. There is no direct evidence of melt loss, but rapid segregation of the melt into leucosomes may explain the lack of extensive retrogression. At the solidus, the $P-T$ path passes into a field in which phengite is again stable, consistent with the cooling path leveling off at approximately 1.2 GPa. Although partial melting did not spark initial exhumation of the North-East Greenland terrane, phengite dehydration melting played an important role as the rocks traveled from 80 to $40 \mathrm{~km}$, including providing water-rich fluid into the gneisses to produce later melts on further cooling.

\section{Acknowledgements}

We dedicate this contribution to the memory of Bruno Lombardo, our good friend and colleague. This research was supported by National Science Foundation grants (EAR-0208236 and 1049433) to Gilotti; and the Shumaker Fund and Faculty Development Fund of the Eberly College of Arts and Sciences at West Virginia University to Lang. We thank C. Menold and an anonymous reviewer for helpful and constructive reviews that improved the final presentation.

We thank D. Wark, J. Pyle and D. Ruscitto for assistance with the microprobe at R.P.I., F. Spear 
711 for many valuable discussions, and D. Tinkham, J. Baldwin and C. de Capitani for assistance 712 with the thermodynamic modeling.

713 

717 Petrology, 152, 125-148.

718

\section{References} London, 164, 709-730.

737

Auzanneau, E., Vielzeuf, D., Schmidt, M.W., 2006. Experimental evidence of decompression melting during exhumation of subducted continental crust. Contributions to Mineralogy and

Baldwin, J.A., Powell, R., Brown, M., Moraes, R., Fuck, R.A., 2005. Modelling of mineral equilibria in ultrahigh-temperature metamorphic rocks from the Ana'polis-Itauc ${ }_{3} \mathrm{U}$ Complex, central Brazil. Journal of Metamorphic Geology, 23, 511-531.

Baldwin J.A., Powell, R., Williams, M.L., Goncalves, P., 2007. Formation of eclogite and reaction during exhumation to mid-crustal levels, Snowbird tectonic zone, western Canada. Journal of Metamorphic Geology, 25, 953-974.

Banno, S., Enami, M., Hirajima T., Ishiwatari A., Wang, Q.C., 2000. Decompression P-T path of coesite eclogite to granulite from Weihai eastern China. Lithos, 52, 97-108.

Berman, R.G., 1988. Internally-consistent thermodynamic data for minerals in the system $\mathrm{Na}_{2} \mathrm{O}-\mathrm{K}_{2} \mathrm{O}-\mathrm{CaO}-\mathrm{MgO}-\mathrm{FeO}-\mathrm{Fe}_{2} \mathrm{O}_{3}-\mathrm{Al}_{2} \mathrm{O}_{3}-\mathrm{SiO}_{2}-\mathrm{TiO}_{2}-\mathrm{H}_{2} \mathrm{O}-\mathrm{CO}_{2}$. Journal of Petrology, 29, 445-522.

Brown, M., 2007. Bicentennial Review: Crustal melting and melt extraction, ascent and emplacement in orogens: mechanisms and consequences. Journal of the Geological Society,

Chopin, C., 2003. Ultrahigh-pressure metamorphism: tracing continental crust into the mantle. Earth and Planetary Science Letters, 212, 1-14. 
740

741

742

743

744 745 746

747 748 749

750

751

752

753

754

755

756

757

758

759

760

761

762

763

764

765

.

Connolly, J.A.D., Petrini, K., 2002. An automated strategy for calculation of phase diagram sections and retrieval of rock properties as a function of physical conditions. Journal of Metamorphic Geology, 20, 697-708.

Coggon, R., Holland, T.J.B, 2002. Mixing properties of phengitic micas and revised garnetphengite thermobarometers. Journal of Metamorphic Geology, 20, 683-696.

de Capitani, C., Petrakakis, K., 2010. The computation of equilibrium assemblage diagrams with Theriak/Domino software. American Mineralogist, 95, 1006-1016.

Dobrzhinetskaya, L.F., Eide, E.A., Larsen, R.B., Sturt, B., Trønnes, R.G., Smith, D.C., Taylor, W.R., Posukhova, T.V., 1995. Microdiamond in high-grade metamorphic rocks of the Western Gneiss region, Norway. Geology 23, 597-600.

Elvevold, S., and Gilotti, J.A., 2000. Pressure-temperature evolution of retrogressed kyanite eclogites, Weinschenk Island, North-East Greenland Caledonides. Lithos 53, 127-147.

57 Ernst, W.G., Hacker, B.R., Liou, J.G., 2007. Petrotectonics of ultrahigh-pressure crustal and upper-mantle rocks: implications for Phanerozoic collisional orogens. Geological Society of America Special Paper 433, 27-49.

Gerya, T.V., Perchuk, L.L., Burg, J.-P., 2008. Transient hot channels: Perpetrating and regurgitating ultrahigh-pressure, high-temperature curst-mantle associations in collision belts. Lithos 103, 236-256.

65 Gilotti, J.A., 2013. The realm of ultrahigh-pressure metamorphism. Elements, 9, 255-260. 
767 Gilotti, J.A., Jones, K.A., Elvevold, S. 2008. Caledonian metamorphic patterns in Greenland. In:

768 Higgins, A.K., Gilotti, J.A., Smith, M.P. (Eds.), The Greenland Caledonides - Evolution of the 769 Northeast Margin of Laurentia. Geological Society of America Memoir 202, 201-225,

771 Gilotti, J.A., McClelland, W.C., 2007. Characteristics of and a tectonic model for ultrahigh-

772 pressure metamorphism in the over-riding plate of the Caledonian orogen. International

773 Geology Review, 49, 777-797.

774

775 Gilotti, J.A., McClelland, W.C., 2011. Geochemical and geochronological evidence that the

776 North-East Greenland ultrahigh-pressure terrane is Laurentian crust. Journal of Geology 119, $777 \quad 439-456$.

778

779 Gilotti, J.A., McClelland, W.C., Wooden, J.L., 2014. Zircon captures exhumation of an ultrahigh780 pressure terrane, North-East Greenland Caledonides. Gondwana Research, 25, 235-256.

781

782 Gilotti, J.A., Nutman, A.P., Brueckner, H.K., 2004. Devonian to Carboniferous collision in the 783 Greenland Caledonides: U-Pb zircon and Sm-Nd ages of high-pressure and ultrahigh-pressure 784 metamorphism. Contributions to Mineralogy and Petrology, 148, 216-235.

786 Gilotti, J.A., Ravna, E.J.K., 2002. First evidence for ultrahigh-pressure metamorphism in the 787 North-East Greenland Caledonides. Geology, 30, 551-554.

789 Gordon, S.M., Little, T.A., Hacker, B.R., Bowring, S.A., Korchinski, M., Baldwin, S.L., Kylander790 Clark, A.R.C., 2012. Multi-stage exhumation of young UHP-UP rocks: Timescales of melt 
791 crystallization in the D'Entrecasteaux Islands, southeastern Papua New Guinea. Earth and 792 Planetary Science Letters 351-352, 237-246.

793

794 Green, E., Holland, T.J.B. Powell, R., 2007. An order-disorder model for omphacitic pyroxenes 795 in the system jadeite-diopside-hedenbergite-acmite with applications to eclogitic rocks.

796 American Mineralogist, 92, 1181-1189.

797 Guiraud, M., Powell, R., Rebay, G., 2001. $\mathrm{H}_{2} \mathrm{O}$ in metamorphism and unexpected behaviour in 798 the preservation of metamorphic mineral assemblages. Journal of Metamorphic Geology, 19, $799 \quad 445-454$.

800

801 Hacker, B.R., 2006. Pressures and temperatures of ultrahigh pressure metamorphism and 802 implications for UHP tectonics and $\mathrm{H}_{2} \mathrm{O}$ in subducting slabs. International Geology Review, 48, $803 \quad 1053-1066$.

804

805 Hacker, B.R., Andersen, T.B., Johnston, S., Kylander-Clark, A.R.C., Peterman, E.M., Walsh, 806 E.O., Young, D., 2010. High-temperature deformation during continental-margin subduction and 807 exhumation: The ultrahigh-pressure Western Gneiss Region of Norway. Tectonophysics 480 , $808 \quad 149-171$.

809

810 Hermann, J., Green, D. H., 2001. Experimental constraints on high pressure melting in 811 subducted crust. Earth and Planetary Science Letters, 188, 149-168.

813 Hermann, J. Rubatto, D., 2014. Subduction of continental crust to mantle depth: Geochemistry 814 of ultrahigh-pressure rocks. In: Holland, H.D., Turekian, K.K., (Eds.) Treatise on Geochemistry, 815 Second Edition 4, 309-340, Oxford: Elsevier. 
817 Hermann, J., Spandler, C.J., 2008. Sediment melts at sub-arc depths: an experimental study.

818 Journal of Petrology, 49, 717-740.

819

820 Hermann, J., Zheng, Y.F., Rubatto, D., 2013. Deep fluids in subducted continental crust.

821 Elements 9, 281-287.

822

823 Higgins, A.K., Gilotti, J.A., Smith M.P. (Eds.), 2008, The Greenland Caledonides: Evolution of

824 the northeast margin of Laurentia. Geological Society of America, Memoir 202, Boulder,

825 Colorado, USA, 368p.

826

827 Holland, T.J.B., Powell, R., 1998. An internally consistent thermodynamic data set for phases of

828 petrological interest. Journal of Metamorphic Geology, 16, 309-344.

829

830 Holland, T.J.B., Powell, R., 2003. Activity-composition relations for phases in petrological

831 calculations: an asymmetric multicomponent formulation. Contributions to Mineralogy and

832 Petrology 145, 492-501.

833

834 Hull, J.M., Friderichsen, J.S., Gilotti, J.A., Henriksen, N., Higgins, A.K., Kalsbeek, F. 1994.

835 Gneiss complex of the Skærfjord region, $76^{\circ}-78^{\circ} \mathrm{N}$, North-East Greenland. Rapport Grønlands

836 Geologiske Undersøgelse 162, 35-51.

837

838 Indares, A., White, R.W., Powell, R., 2008. Phase equilibria modeling of kyanite-bearing

839 anatectic paragneisses from the central Grenville Province. Journal of Metamorphic Geology

$840 \quad 26,815-836$.

841 
842 Kalsbeek, F., Thrane, K., Higgins, A.K., Jepsen, H., Leslie, A.G., Nutman, A.P., Frei, R. 2008.

843 Polyorogenic history of the East Greenland Caledonides. In: Higgins, A.K., Gilotti, J.A., Smith,

844 M. P. (Eds.), The Greenland Caledonides: evolution of the northeast margin of Laurentia.

845 Geological Society of America Memoir 202, 55-72.

846

847 Konrad-Schmolke, M., O'Brien, P.J., de Capitani, C., Carswell, D.A., 2008. Garnet growth at 848 high- and ultra-high pressure conditions and the effect of element fractionation on mineral 849 modes and composition. Lithos 103, 309-332.

850

851 Kotková, J., Harley, S.L., 2010. Anatexis during high-pressure crustal metamorphism: evidence

852 from Garnet-Whole-rock REE relationships and zircon-rutile $\mathrm{Ti}-\mathrm{Zr}$ thermometry in

853 leucogranulites from the Bohemian Massif. Journal of Petrology 51, 1967-2001.

854

855 Kotková, J., O’Brien, P.J., Ziemann, M.A., 2011. Diamond and coesite discovered in Saxony-

856 type granulite: Solution to the Variscan garnet peridotite enigma. Geology 39, 667-670.

857

858 Labrousse, L., Jolivet, L., Agard, P., Herbert, R., Andersen, T.B., 2002. Crustal-scale boudinage

859 and migmatization of gneiss during their exhumation in the UHP province of Western Norway.

860 Terra Nova 4, 263-270.

861

862 Labrousse, L., Prouteau, G., Ganzhorn, A.-C., 2011. Continental exhumation triggered by

863 partial melting at ultrahigh pressure. Geology 39, 1171-1174.

864

865 Lang, H.M., Gilotti, J.A., 2007. Partial melting of metapelites at ultrahigh-pressure conditions, 866 Greenland Caledonides. Journal of Metamorphic Geology 25, 129-147.

867 
868 Liu, A., Hermann, J., Zhang, J., 2013. Polyphase inclusions in the Shuanghe UHP eclogites

869 formed by subsolidus transformation and incipient melting during exhumation of deeply

870 subducted crust. Lithos 177, 91-109.

871

872 Massonne, H.-J., 2009. Hydration, dehydration, and melting of metamorphosed granitic and 873 dioritic rocks at high- and ultrahigh-pressure conditions. Earth and Planetary Science Letters $874288,244-254$.

875

876 Massonne, H.-J., 2013. Constructing the pressure-temperature path of ultrahigh-pressure 877 rocks. Elements 9, 267-272.

878

879 Massonne, H.-J., Fockenberg, T., 2012. Melting of metasedimentary rocks at ultrahigh

880 pressure-Insights from experiments and thermodynamic calculations. Lithosphere 4, 269-285.

881

882 McClelland, W.C., Gilotti, J.A., Mazdab, F.K., Wooden, J.L., 2009. Trace-element record in 883 zircons during exhumation from UHP conditions, North-East Greenland Caledonides. European 884 Journal of Mineralogy 21, 1135-1148.

885

886 McClelland, W.C., Lapen, T.J., 2013. Linking time to the pressure-temperature path for 887 ultrahigh-pressure rocks. Elements 9, 273-279.

888

889 McClelland, W.C., Power, S.E., Gilotti, J.A., Mazdab, F.K., Wopenka, B., 2006. U-Pb SHRIMP 890 geochronology and trace-element geochemistry of coesite-bearing zircons, North-East 891 Greenland Caledonides. In: Ultrahigh-pressure metamorphism: Deep continental subduction 892 Hacker, B.R., McClelland, W.C., Liou, J.G. (Eds.). Geological Society of America Special 893 Paper, 403, 23-43. 
895 Mechie, J., Kind, R., Saul, J., 2012. The seismological structure of the Tibetan Plateau crust and 896 mantle down to 700 km depth. In: Gloaguen, R., Ratschbacher, L. (Eds.), Growth and Collapse 897 of the Tibetan Plateau. Geological Society London Special Publication 353, 109-125.

Menold, C.A., Manning, C.E., Yin, A., Tropper, P., Chen, X.-H., Wang, X.-F., 2009.

Metamorphic evolution, mineral chemistry and thermobarometry of orthogneiss hosting

901

902

903

904

905

906

907

908

909

910

911

912

913

914

915

916

917 Prince, C., Harris, N.B.W., Vance, D., 2001. Fluid-enhanced melting during prograde

918 metamorphism. Journal of the Geological Society of London 158, 233-242.

ultrahigh-pressure eclogites in the North Qaidam metamorphic belt, western China. Journal of Asian Earth Sciences 35, 273-284.

Mposkos, E., Krohe, A., 2006. Pressure-temperature-deformation paths of closely associated ultra-high-pressure (diamond-bearing) crustal and mantle rocks of the Kimi complex: implications for the tectonic history of the Rhodope Mountains, northern Greece. Canadian Journal of Earth Science 43, 1755-1776.

Pattison, D.R.M., Begin, N.J., 1994. Hierarchy of closure temperatures in granulites and the importance of an intergranular exchange medium (melt?) in controlling maximum Fe-Mg exchange temperatures. Mineralogical Magazine 58A, 694-695.

Powell, R., Holland, T. J. B., 1988. An internally consistent thermodynamic dataset with uncertainties and correlations: 3. Application, methods, worked examples and a computer program. Journal of Metamorphic Geology 6, 173-204.

$$
\text { metamorphism. Journal of the Geological Society of London 158, 233-242. }
$$


920 Ragozin, A.L., Liou, J.G., Shatsky, V.S., Sobolev, N.V., 2009. The timing of the retrograde

921 partial melting in the Kumdy-Kol region (Kokchetav Massif, Northern Kazakhstan). Lithos 109,

$922 \quad 274-284$.

923

924 Rosenberg, C.L., Handy, M.R., 2005. Experimental deformation of partially melted granite 925 revisited: implications for the continental crust. Journal of Metamorphic Geology 23, 19-28.

926

927 Rubatto, D., Hermann, J., Berger, A., Engi, M., 2009. Protracted fluid-induced melting during

928 Barrovian metamorphism in the Central Alps. Contributions to Mineralogy and Petrology 158, $929 \quad 703-722$.

930

931 Rumble, D., 1998, Stable isotope geochemistry of ultrahigh pressure rocks. In: Hacker, B.R., 932 and Liou, J.G. (Eds.). When continents collide: Dordrecht, Netherlands, Kluwer Academic, 241 933260.

934

935 Schmidt, M.W., Vielzeuf, D., Auzanneau, E., 2004. Melting and dissolution of subducting crust 936 at high pressures: the key role of white mica. Earth and Planetary Science Letters 228, 65-84.

938 Spear F.S., 1993. Metamorphic Phase Equilibria and Pressure-Temperature-Time Paths.

939 Washington D.C., Mineralogical Society of America Monograph I, 799 p.

940

941 Storm, L. C., Spear, F.S., 2005. Pressure, temperature and cooling rates of granulite facies

942 migmatitic pelites from the southern Adirondack Highlands, New York. Journal of Metamorphic 943 Geology 23, 107-130.

944 
945 Terry, M.P., Robinson, P., Ravna, E.J.K., 2000. Kyanite eclogite thermobarometry and evidence

946 for thrusting of UHP over HP metamorphic rocks, Nordøyane, Western Gneiss Region, Norway.

947 American Mineralogist 85, 1637-1650.

948

949 Tinkham, D.K., Zuluaga, C.A., Stowell, H.H., 2001. Metapelite phase equilibria modeling in

$950 \mathrm{MnNCKFMASH}$ : The effect of variable $\mathrm{Al}_{2} \mathrm{O}_{3}$ and $\mathrm{MgO} /(\mathrm{MgO}+\mathrm{FeO})$ on mineral stability.

951 Geological Materials Research 3, 1-42.

952

953 Tinkham, D.K., Ghent, E.D., 2005. Estimating $P-T$ conditions of garnet growth with isochemical 954 phase-diagram sections and the problem of effective bulk-composition. Canadian Mineralogist $95543,35-50$.

956

957 Wallis, S., Tsuboi, M., Suzuki, K., Fanning, M., Jiang, L., Tanaka, T., 2005. Role of partial 958 melting in the evolution of the Sulu (eastern China) ultrahigh-pressure terrane. Geology 33, 129959132.

960

961 Walsh, E.O., Hacker, B.R., 2004. The fate of subducted continental margins: Two-stage

962 exhumation of the high-pressure to ultrahigh-pressure Western Gneiss Region, Norway.

963 Journal of Metamorphic Geology 22, 671-687.

964

965 Waters, D.J., 2001. The significance of prograde and retrograde quartz-bearing intergrowth 966 microstructures in partially melted granulite-facies rocks. Lithos 56, 97-110.

967

968 White, R.W., Powell, R, 2002. Melt loss and the preservation of granulite facies mineral 969 assemblages. Journal of Metamorphic Geology 20, 621-632. 
971 White, R.W., Powell, R., Holland, T.J.B., 2001. Calculation of partial melting equilibria in the 972 system $\mathrm{Na}_{2} \mathrm{O}-\mathrm{CaO}-\mathrm{K}_{2} \mathrm{O}-\mathrm{FeO}-\mathrm{MgO}-\mathrm{Al}_{2} \mathrm{O}_{3}-\mathrm{SiO}_{2}-\mathrm{H}_{2} \mathrm{O}$ (NCKFMASH). Journal of Metamorphic 973 Geology 19, 139-153.

974

975 White, R.W., Powell, R., Holland, T.J.B., 2007. Progress relating to calculation of partial melting 976 equilibria for metapelites. Journal of Metamorphic Geology 25, 511-527.

977

978 Whitney, D.L., Evans, B.W., 2010. Abbreviations for names of rock-forming minerals. American 979 Mineralogist 95, 185-187.

980

981 Whitney, D., Teyssier, C., Rey, P.F., 2009. The consequences of crustal melting in continental 982 subduction. Lithosphere 1, 323-327.

983

984 Wittlinger, G., Vergne, J., Tapponnier, P., Farra, V., Poupinet, P., Jiang, M., Su, H., Herquel, G., 985 Paul, A., 2004. Teleseismic imaging of subducting lithosphere and Moho offsets beneath 986 western Tibet. Earth and Planetary Science Letters 221, 117-130.

987

988 Zheng, Y-F, Xia, Q-X, Chen, R-X, Gao, X-Y, 2011. Partial melting, fluid supercriticality and 989 element mobility in UHPM rocks during continental collision. Earth-Science Reviews 107, 342990374.

991

992 Zuluaga, C.A., Stowell, H.H., Tinkham, D.K., 2005. The effect of zoned garnet on metapelite 993 pseudosection topology and calculated metamorphic $P-T$ paths. American Mineralogist 90 , $994 \quad 1619-1628$. 


\section{List of Tables}

996 Table 1. Bulk Sample Compositions by X-ray Fluorescence (XRF).

997 Table 2. Low grossular garnet core compositions.

998 Table 3. Calculated Liquid Compositions.

\section{Figure Captions}

1001 Figure 1. Map of the ultrahigh-pressure terrane on Rabbit Ears Island (REI) shows lithologies

1002 and sample locations. Most of the mafic eclogites are too small to show on the map. The inset 1003 shows the location of the NEGEP by a box in the gray-shaded area of the Caledonides.

Figure 2. (a) Outcrop photograph showing a garnet-rich leucosome on the right and typical pelitic paragneiss with various proportions of leucosome on the left. The foliation is near 1007 vertical; the pencil is $14 \mathrm{~cm}$ long. (b) A thin section scan of sample 03-127c showing the garnet megacryst in Figure 3 and its surrounding matrix. Black arrows indicate leucosomes and white arrows indicate quartz bands. (c) Photomicrograph of two polycrystalline quartz inclusions in a garnet megacryst of sample 03-127c, surrounded by trapped, crystallized melt (arrows), in plane

1011 polarized light. Note radial cracks in garnet around the quartz inclusions. (d) Same as (c) in 1012 cross-polarized light.

1014 Figure 3. (a) Ca X-ray map of a garnet megacryst in section 03-127c (Fig. 2b). Warm colors 1015 indicate high-Ca, (see color bar at right). The white line outlining garnet is necessary because 1016 the boundary is difficult to distinguish from the plagioclase-rich matrix that contains small garnet 1017 grains. (b) Fe X-ray map; the white line defining the garnet boundary was drawn from this 1018 image. (c) Mg X-ray map. (d) Ca X-ray map with black ovals indicating the restitic core (inside 1019 the dashed black line) and the rim that grew during decompression (outside the dashed line). 
(e) Expanded Ca X-ray map of the portion of the garnet megacryst rim outlined in Fig. 3a. (f)

1021 Photomicrograph of the same portion of the garnet rim shown in Fig. 3e.

1023 Figure 4. P-T pseudosections for two paragneiss samples. Fields are labeled with 1024 abbreviations for all the phases present (after Whitney and Evans, 2010). Some labels are 1025 omitted for clarity. The variance of each field is indicated by shading; darkest gray corresponds 1026 to highest variance. The bold black line marks the solidus, the star represents peak UHP 1027 conditions, and the wide dashed lines indicate possible initial decompression paths discussed in 1028 the text. (a) Sample 03-126 with 4 moles hydrogen per 100 moles of cations, or $2 \mathrm{~mole} \% \mathrm{H}_{2} \mathrm{O}$ 1029 and approximately 0.7 wt. $\% \mathrm{H}_{2} \mathrm{O}$. (b) Sample $03-126$ with 14 mole\% of restitic garnet core 1030 composition subtracted (see text for discussion). (c) Sample 03-127, with 4 moles hydrogen per 1031100 moles of cations.

1032

1033 Figure 5. (a) Calculated Pressure-mole\% $\mathrm{H}_{2} \mathrm{O}$ diagram at constant temperature for sample 031034 126. Each field is labeled with the stable assemblage and the variance is indicated by gray1035 scale. The solidus is indicated by a bold dashed line. (b) Pressure-mole $\% \mathrm{H}_{2} \mathrm{O}$ at $950^{\circ} \mathrm{C}$ contoured for $\mathrm{X}_{\mathrm{Alm}}, \mathrm{X}_{\mathrm{Prp}}, \mathrm{X}_{\mathrm{Grs}}$ in garnet and $\mathrm{Si}$ in phengite. The average values of $\mathrm{X}_{\mathrm{Alm}}, \mathrm{X}_{\mathrm{Prp}}, \mathrm{X}_{\mathrm{Grs}}$

1037 in low grossular garnet cores (Table 2) and maximum Si in phengite are indicated by thick 1038 colored lines that highlight the contours corresponding to their compositions. Si in phengite is 1039 consistent, but does not provide a precise constraint on $\mathrm{H}_{2} \mathrm{O}$ content.

Figure 6. P-T pseudosections for sample 03-126 H4 contoured for volume\% and compositional 1042 parameters. (a) Volume\% liquid, volume\% phengitic white mica and calculated Si in white mica. 1043 (b) Volume\% clinopyroxene and calculated $\mathrm{X}_{\mathrm{Jd}}$ in clinopyroxene. (c) Volume\% garnet and 1044 calculated $\mathrm{X}_{\mathrm{Grs}}$ in garnet. Fields of maximum volume\% garnet and maximum $\mathrm{X}_{\mathrm{Grs}}$ are shown in 1045 purple and blue respectively. (d) $\mathrm{X}_{\mathrm{Alm}}$ and $\mathrm{X}_{\mathrm{Prp}}$ in garnet. Peak UHP conditions are indicated by 
1046

1047

1048

1049

1050

1051

1052

1053

1054

1055

1056

1057

1058

1059

1060

1061

1062

1063

1064

1065

1066

1067

1068

1069

1070

1071

a star on this and other pseudosections. Possible decompression paths, indicated by thick dashed lines, are discussed in the text.

Figure 7. Pseudosection 03-126 H4 with volume\% garnet contours and maximum garnet volume indicated. Peak conditions and possible initial decompression paths are shown as in Fig. 4 and 6. The most likely low pressure cooling path (thick dashed line at approximately 1.2 GPa) is constrained by the assemblage in leucosomes, i.e., Ph, Grt, Bt, 2 Fsp, Ky, Qz and Rt. Placing the path parallel to the garnet isopleths minimizes garnet consumption, which is consistent with observations.

Figure 8. Calculated feldspar volumes and compositions for sample 03-126 H4 are shown throughout the region of interest. The solidus is indicated by a bold black line and the preferred $P-T$ path is show as a thick black dashed line. (a) Contours of volume\% alkali feldspar and plagioclase are shown in appropriate fields. (b) Compositional contours of anorthite, albite and sanidine in alkali feldspar in all fields where it is stable. (c) Contours of albite and anorthite components in plagioclase feldspar in the two feldspar field.

Figure 9. The calculated $P-T$ section for $03-126 \mathrm{H} 4$ is shown with the preferred $P-T$ path (dashed black line), and the two-segment approximate path (wide gray line), which is the basis of the PT-n and PT-X sections of Fig. 10. PT0 through PT8 are referred to in the text. Approximate ages at several stages are indicated on the path.

Figure 10. (a) Calculated isochemical $P T-n$ section, which indicates the calculated number of moles $(n)$ of each important phase in sample 03-126 at pressures and temperatures along the two-segment $P-T$ path of Fig. 9. Note that pressure decreases from $3.6 \mathrm{GPa}$ to $1.3 \mathrm{GPa}$ from left to center along the $X$-axis to represent the near-isothermal decompression path. There is a 
1072 change in scale at $1.3 \mathrm{GPa}, 930^{\circ} \mathrm{C}$ at the center of the X-axis (PT5). Along the right half of the $1073 \mathrm{X}$-axis, temperature decreases from $930^{\circ} \mathrm{C}$ to $640^{\circ} \mathrm{C}$ to represent the near-isobaric cooling path.

1074 (b) $P T-X$ pseudosection showing variation in mole fraction $(X)$ of important mineral solid1075 solution components along the two-segment $P-T$ path for sample 03-126. Example of mole 1076 fraction notation: $\mathrm{Cel}(\mathrm{Ph})$ is $\mathrm{X}_{\text {celadonite }}$ in phengitic white mica. 


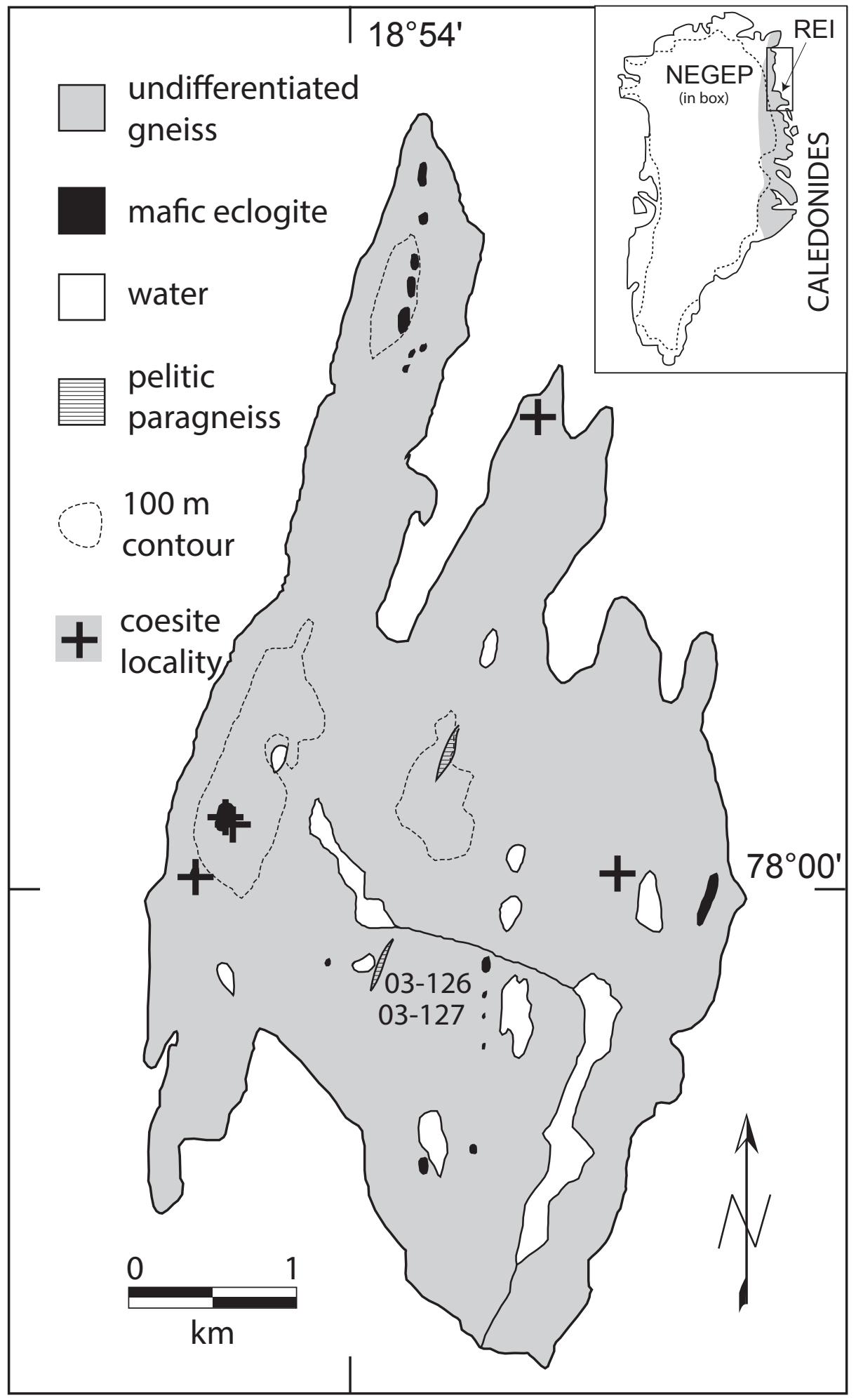



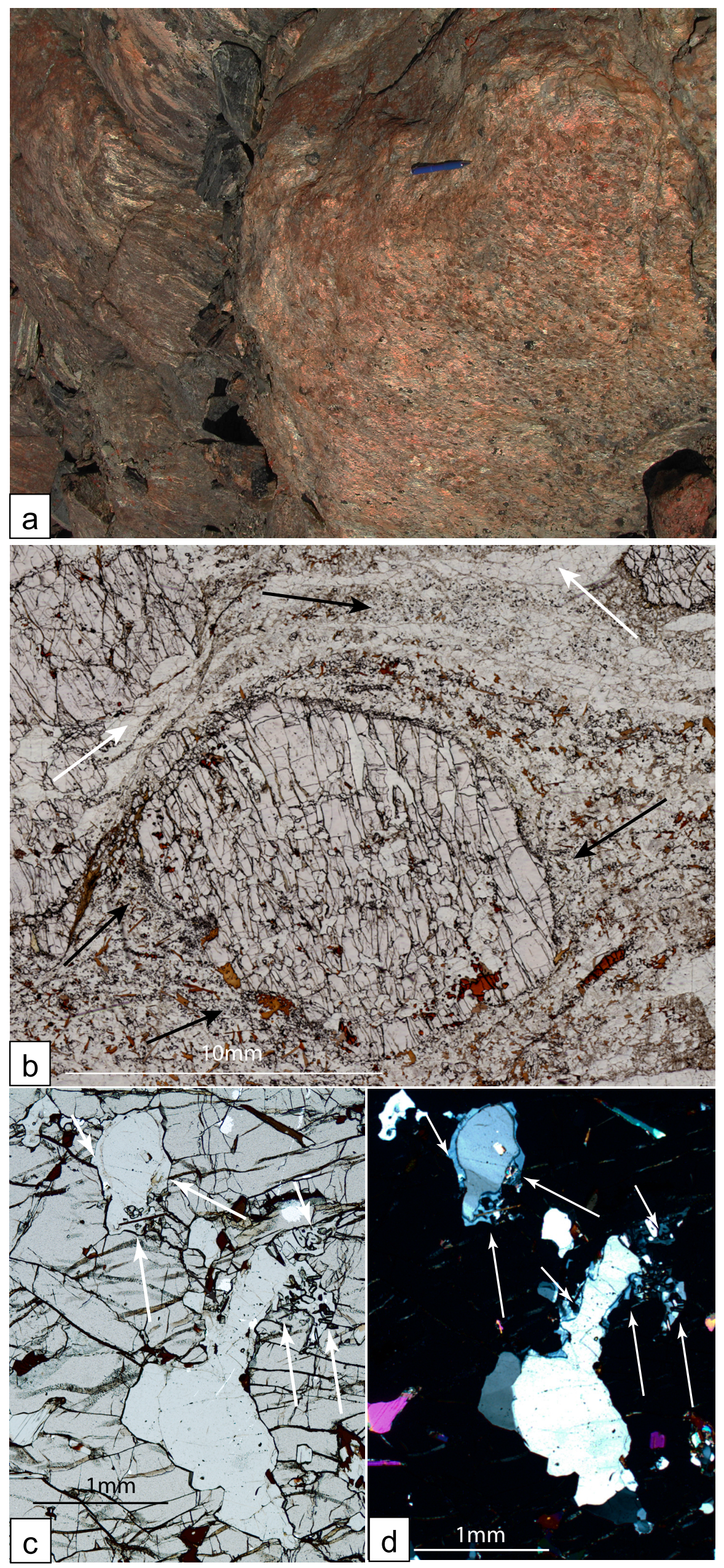

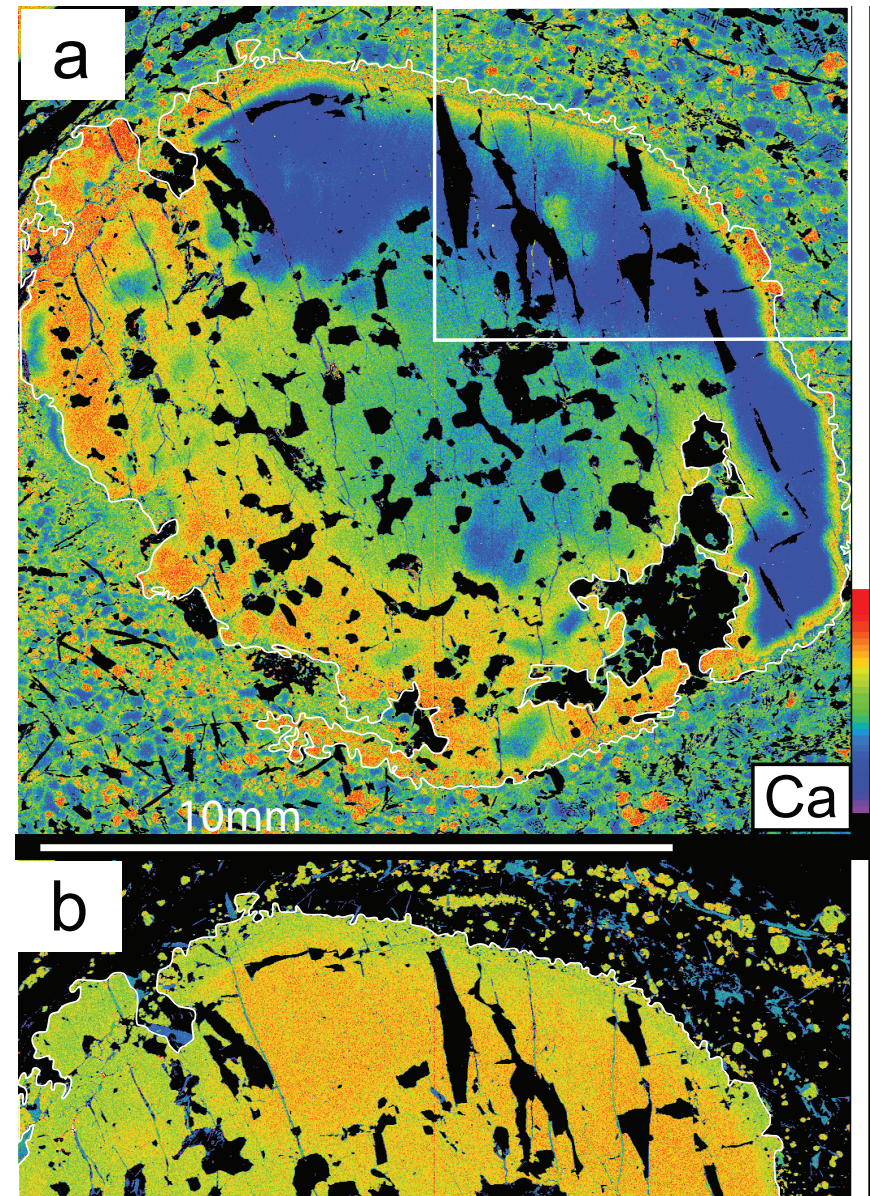

- -1

- $\times 1011$ $+2=25$

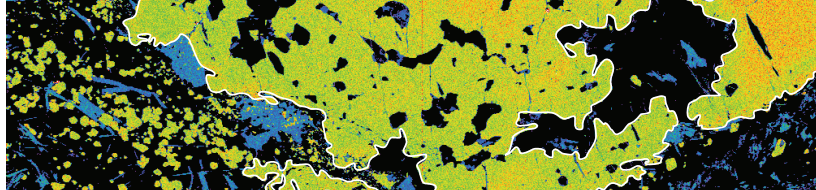

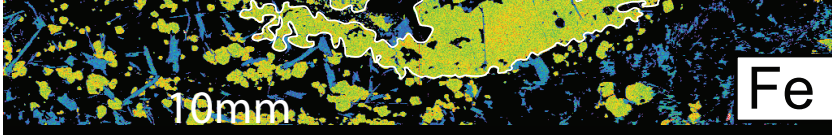

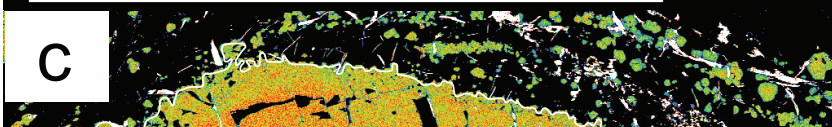
Fo ith - $-\mathrm{d}+\mathrm{H}$

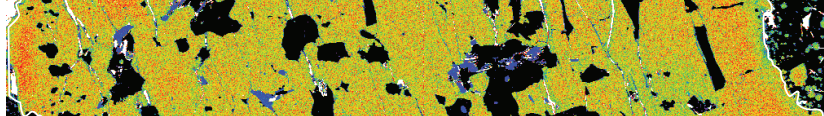

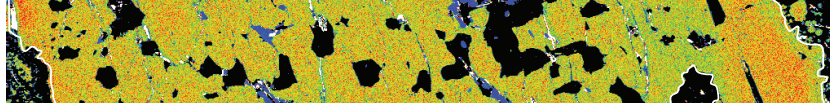

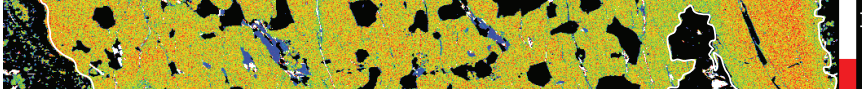

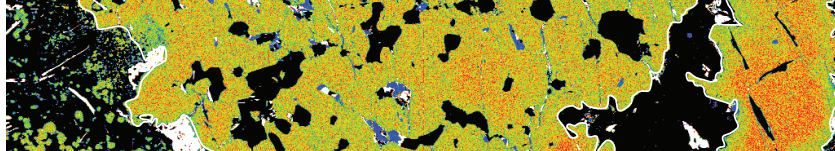
$0,0, \%$ - $x+x^{*}-1$

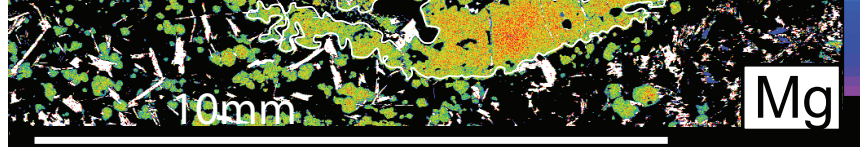
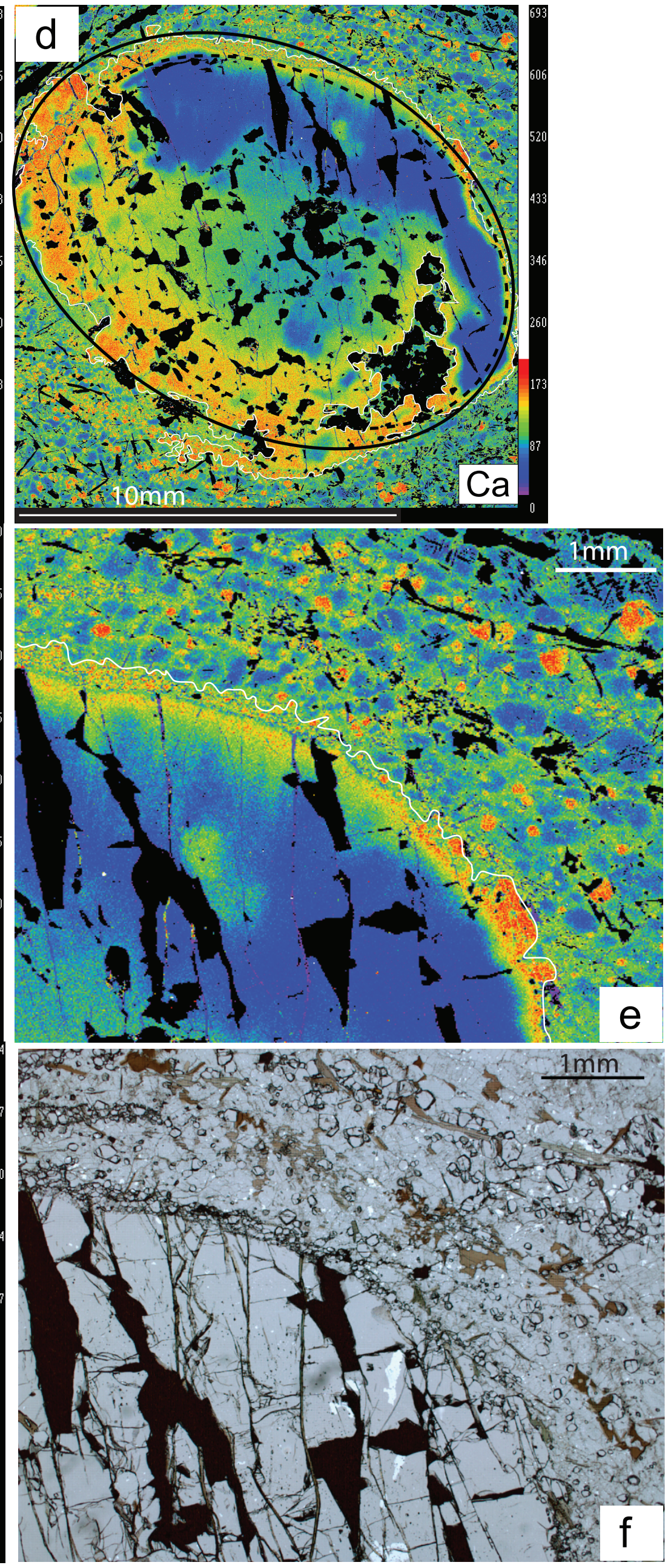

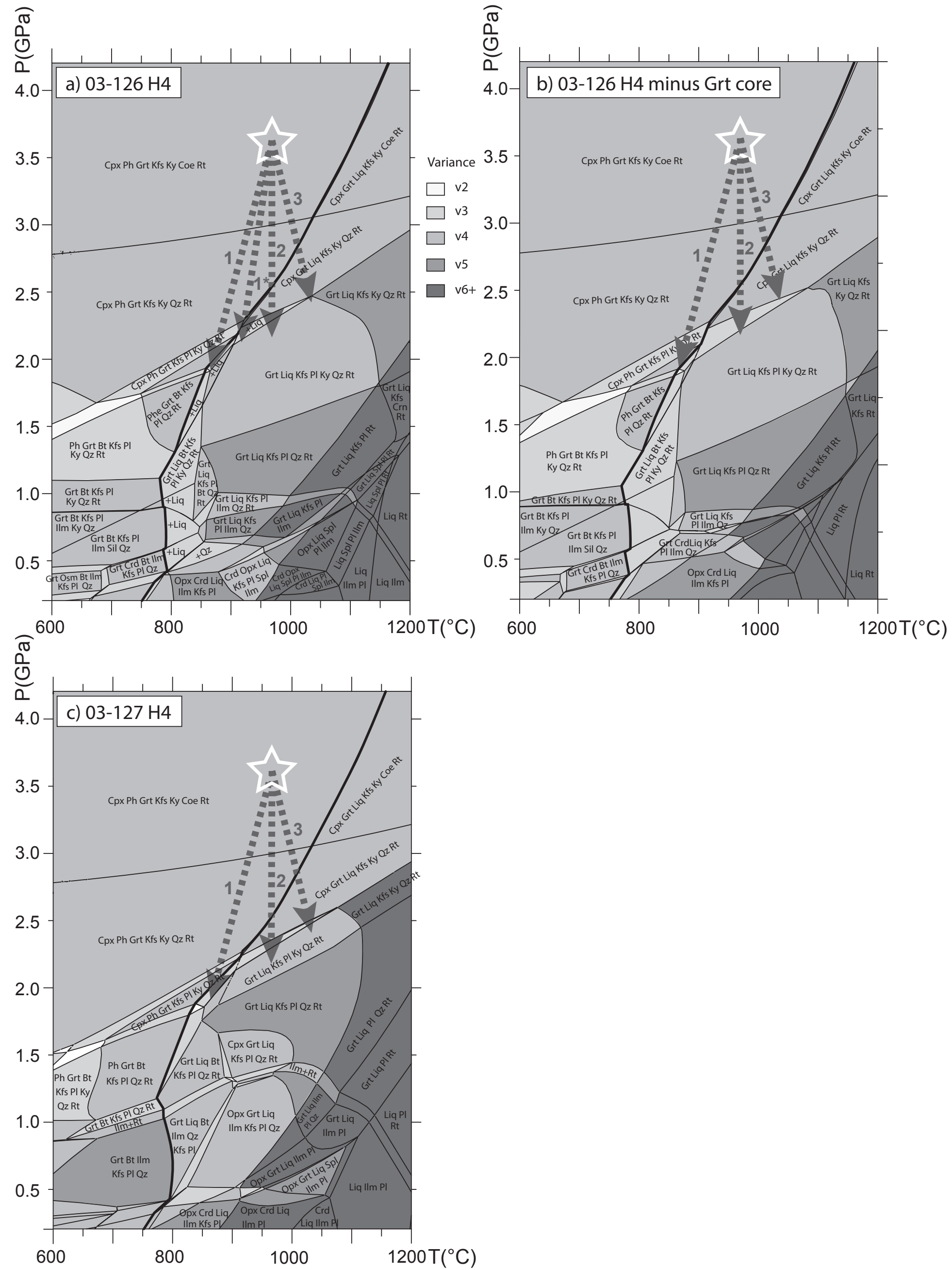
Figure 6

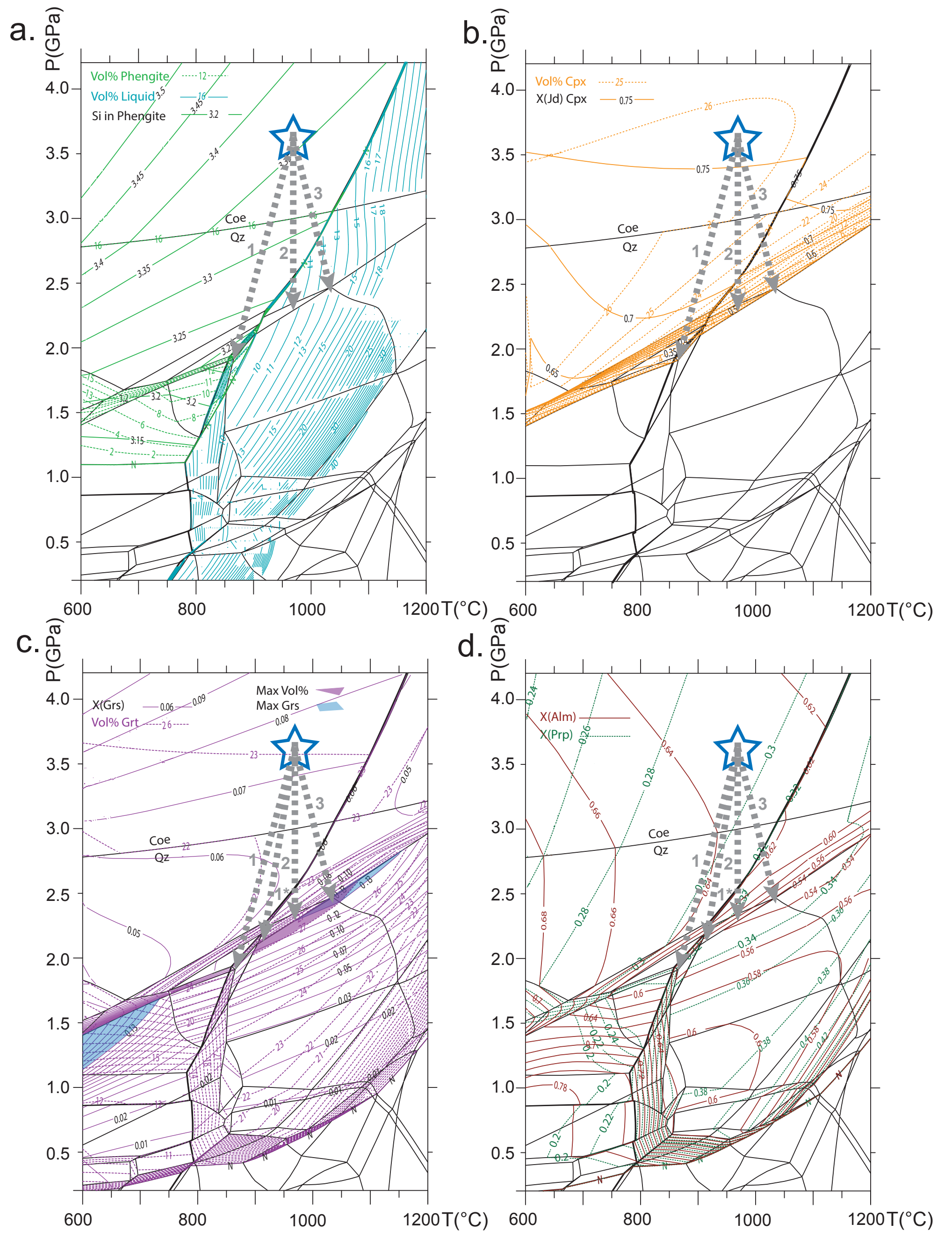


Figure 7

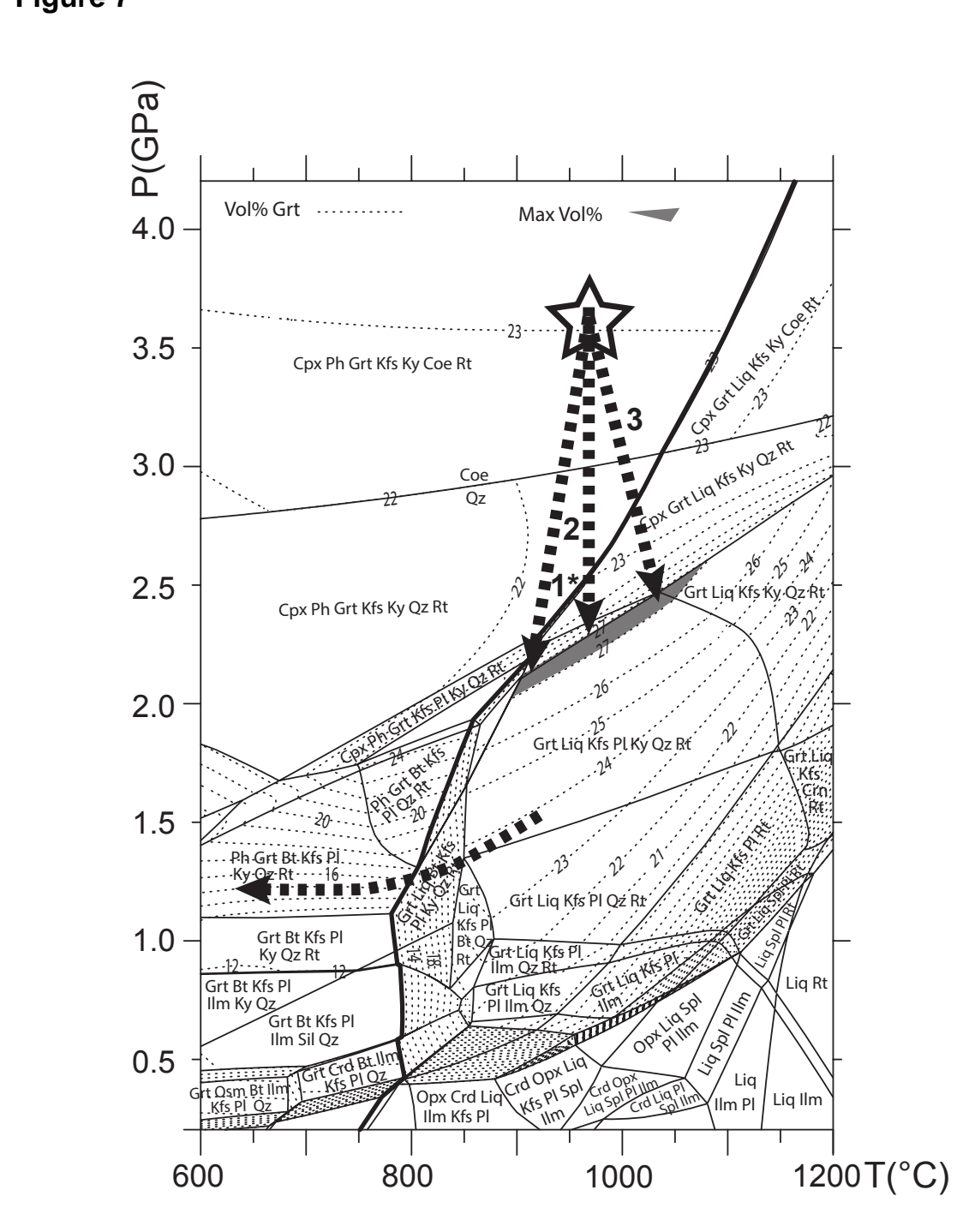


a.

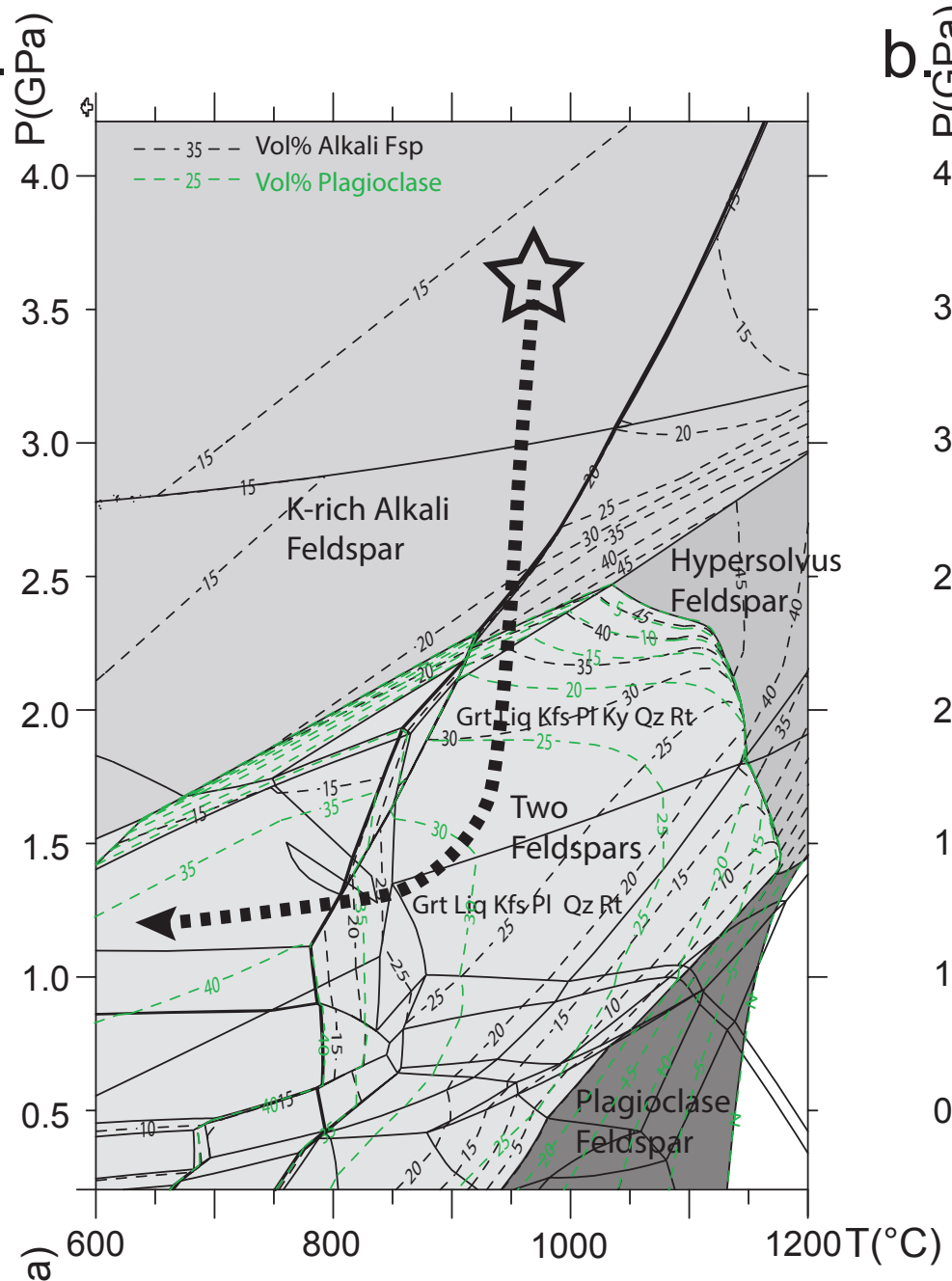

c.

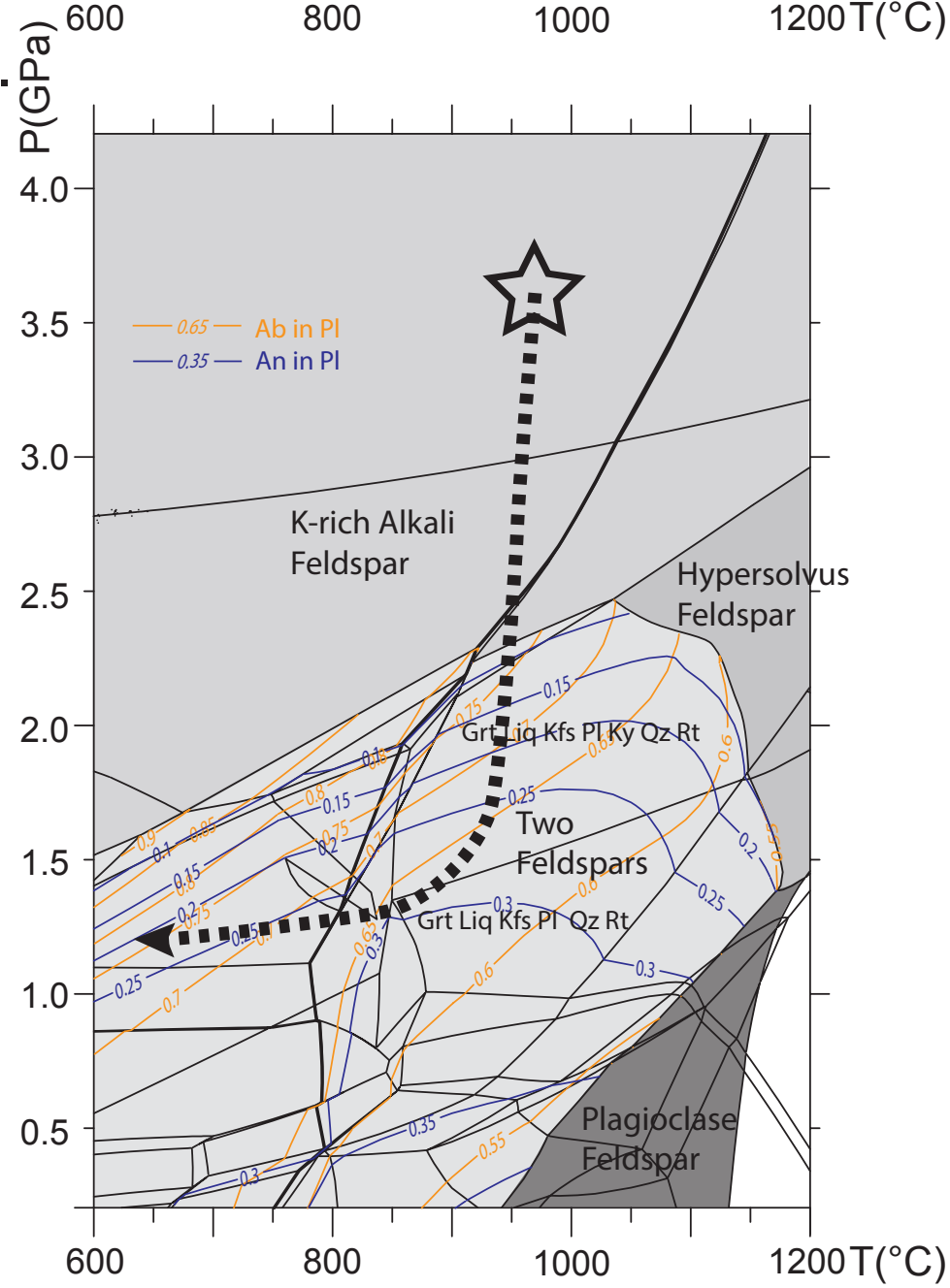

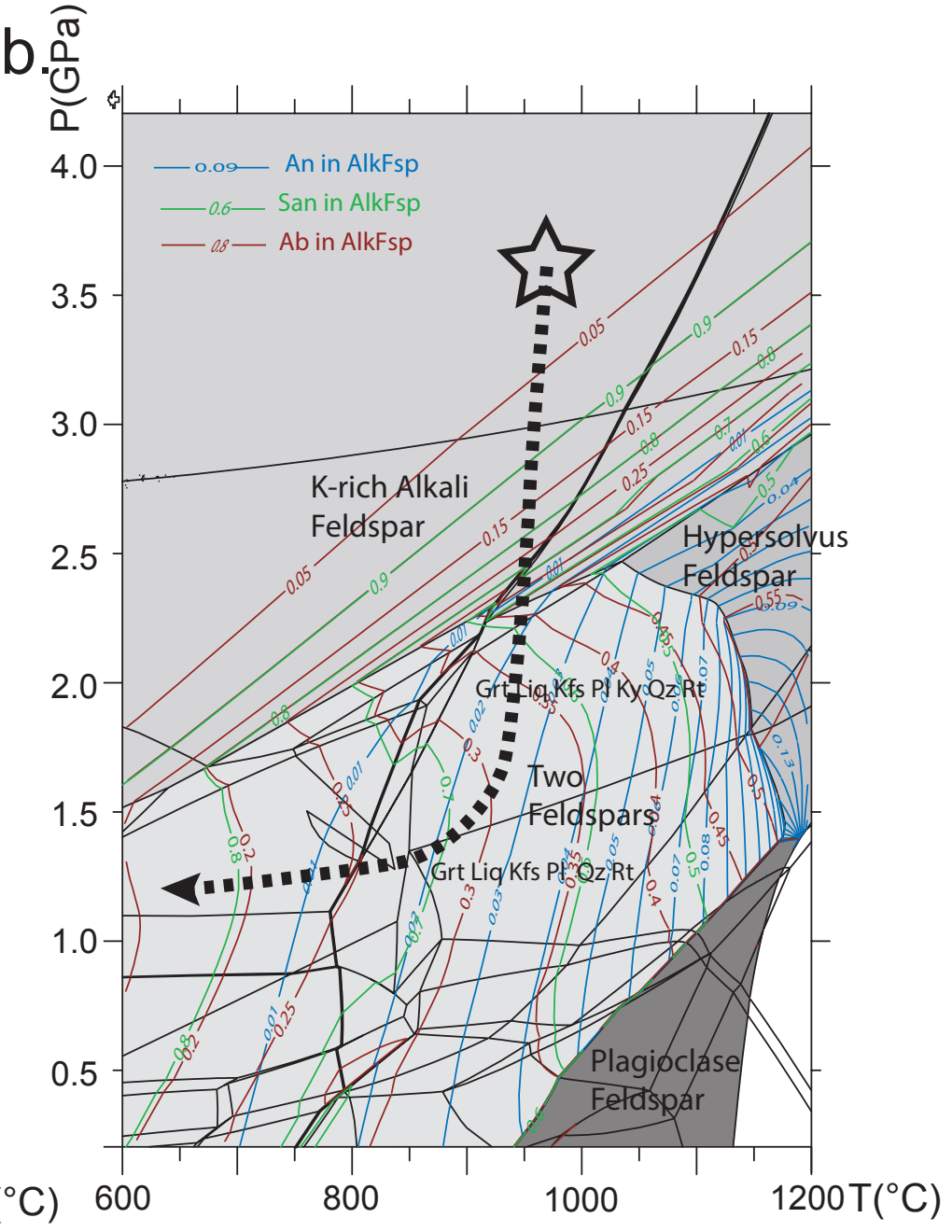

6. 
Figure 9

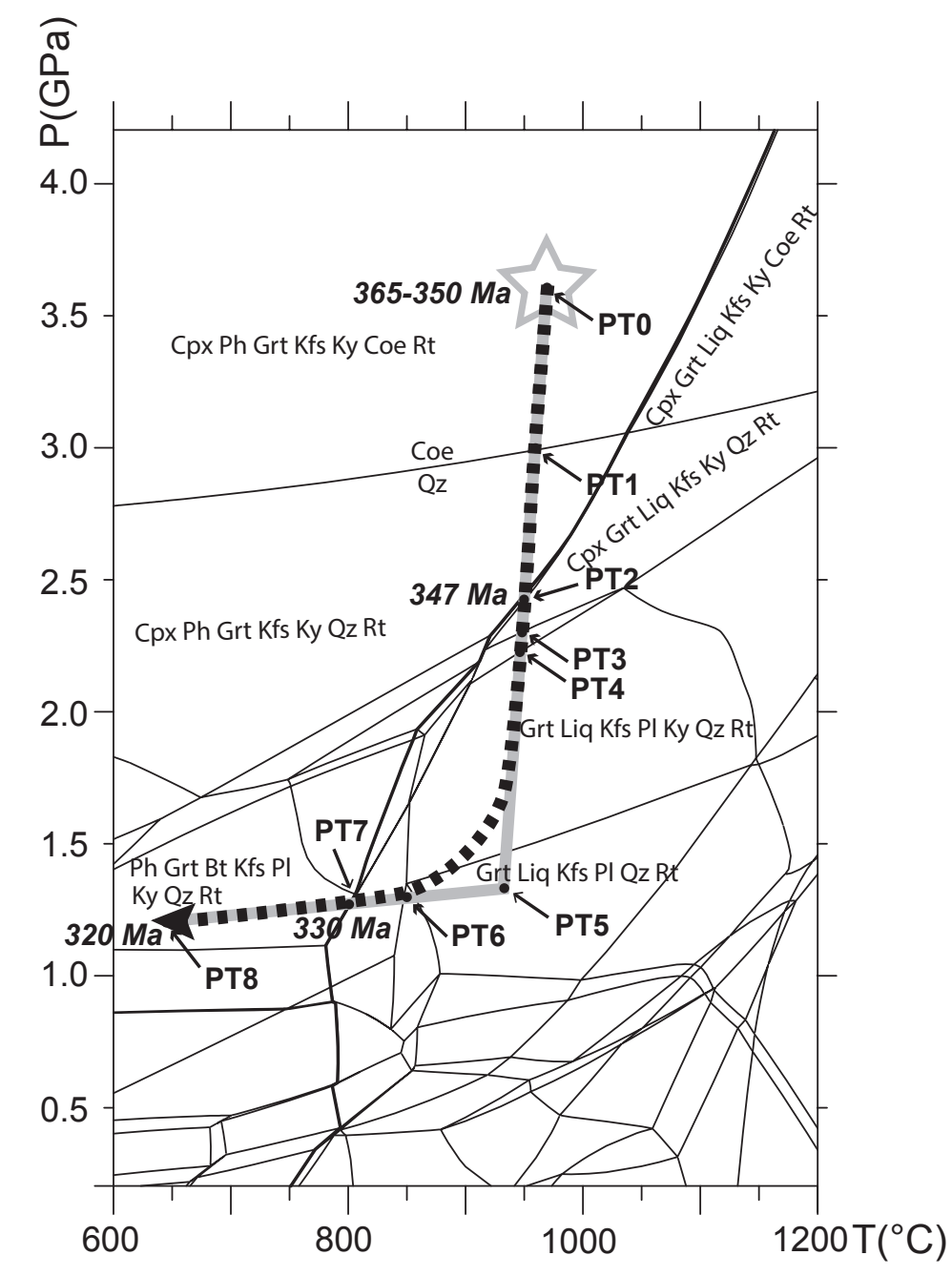




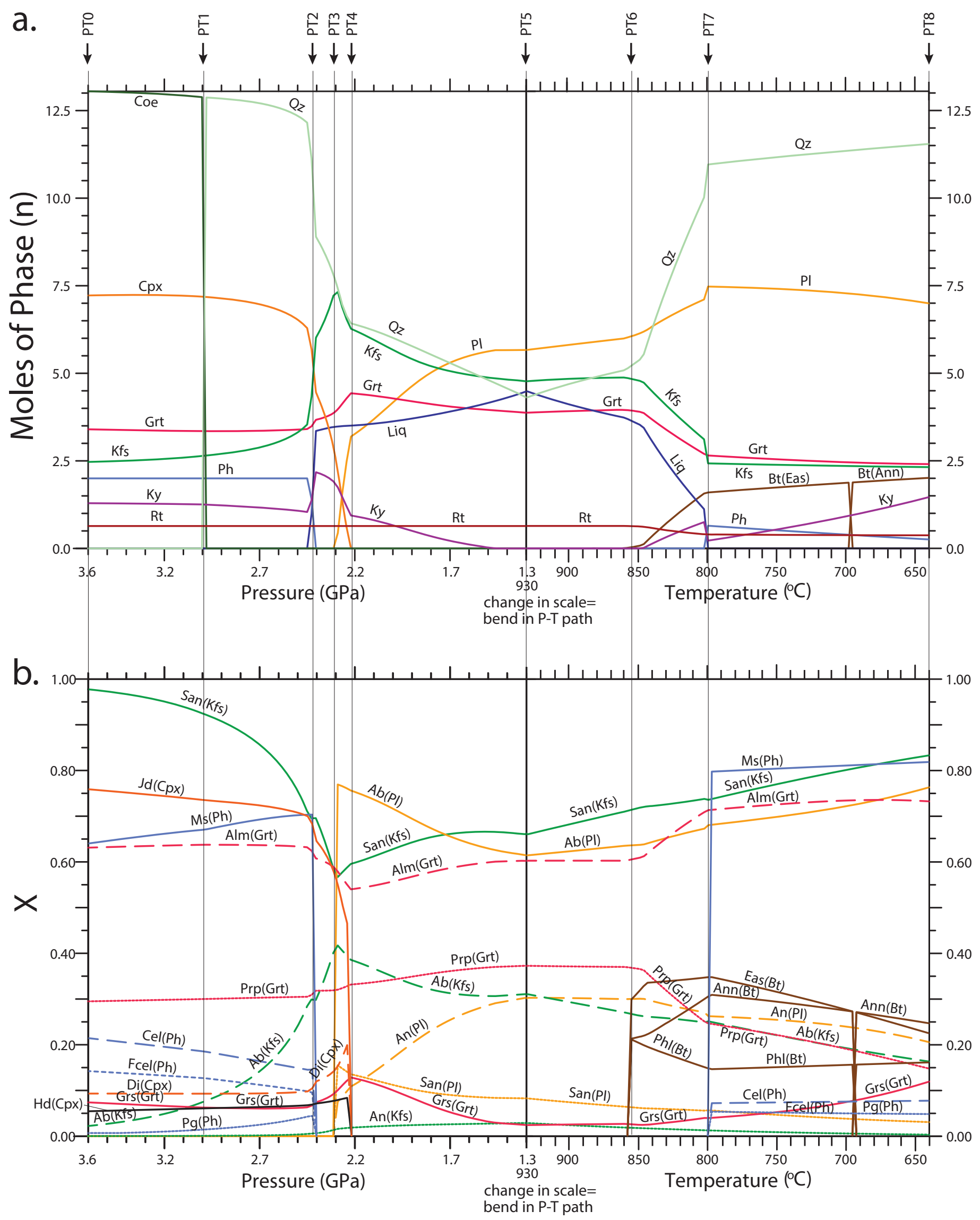


Table 1. Bulk Sample Compositions by X-ray Flourescence (XRF)*

\begin{tabular}{|c|c|c|c|}
\hline & $03-126$ & $03-126$ & 03-127 \\
\hline \multicolumn{4}{|c|}{-Garnet core } \\
\hline \multicolumn{4}{|c|}{ Unnormalized Major Elements (Weight \%): } \\
\hline $\mathrm{SiO} 2$ & 56.60 & 60.20 & 55.28 \\
\hline TiO2 & 0.91 & 1.07 & 1.61 \\
\hline $\mathrm{Al} 2 \mathrm{O} 3$ & 19.97 & 19.89 & 19.05 \\
\hline $\mathrm{FeO}$ & 9.25 & 5.95 & 11.80 \\
\hline $\mathrm{MnO}$ & 0.09 & & 0.10 \\
\hline $\mathrm{MgO}$ & 3.18 & 2.47 & 3.15 \\
\hline $\mathrm{CaO}$ & 2.29 & 2.40 & 3.54 \\
\hline $\mathrm{Na} 2 \mathrm{O}$ & 3.15 & 3.70 & 2.91 \\
\hline $\mathrm{K} 2 \mathrm{O}$ & 3.68 & 4.32 & 2.30 \\
\hline P2O5 & 0.06 & & 0.03 \\
\hline total & 99.18 & 100.00 & 99.76 \\
\hline Mn-P free & \multicolumn{3}{|c|}{ Unnormalized Major Elements (Weight \%): } \\
\hline $\mathrm{SiO} 2$ & 56.60 & 60.20 & 55.28 \\
\hline TiO2 & 0.91 & 1.07 & 1.61 \\
\hline $\mathrm{Al} 2 \mathrm{O} 3$ & 19.97 & 19.89 & 19.05 \\
\hline $\mathrm{FeO}$ & 9.25 & 5.95 & 11.80 \\
\hline $\mathrm{MgO}$ & 3.18 & 2.47 & 3.15 \\
\hline $\mathrm{CaO}$ & 2.29 & 2.40 & 3.54 \\
\hline $\mathrm{Na} 2 \mathrm{O}$ & 3.15 & 3.70 & 2.91 \\
\hline $\mathrm{K} 2 \mathrm{O}$ & 3.68 & 4.32 & 2.30 \\
\hline total & 99.04 & 100.00 & 99.63 \\
\hline Mn-P free & \multicolumn{3}{|l|}{ Mole\% cations } \\
\hline $\mathrm{Si}$ & 53.11 & 55.55 & 52.21 \\
\hline $\mathrm{Ti}$ & 0.64 & 0.74 & 1.15 \\
\hline $\mathrm{Al}$ & 22.10 & 21.64 & 21.21 \\
\hline $\mathrm{Fe}$ & 7.26 & 4.59 & 9.32 \\
\hline $\mathrm{Mg}$ & 4.45 & 3.40 & 4.43 \\
\hline $\mathrm{Ca}$ & 2.31 & 2.37 & 3.58 \\
\hline $\mathrm{Na}$ & 5.73 & 6.62 & 5.34 \\
\hline K & 4.40 & 5.09 & 2.77 \\
\hline sum & 100.00 & 100.00 & 100.00 \\
\hline
\end{tabular}


Table 2. Low Grossular Garnet Core compositions

03-126c Garnet Map 3

Point\#

87
0.616

88

$X^{\prime}$ Alm

0.616

0.609

$X^{\prime} \operatorname{Prp}$

0.340

0.343

98

0.045

0.048

0.338

101

102

Mean

X' Grs

0.060

0.332

0.603

0.330

0.068

03-127c Garnet Map 0

Point\#

146

$X^{\prime}$ Alm

0.676

0.268

147

147

148

148
0.665

(2)

$X^{\prime} \operatorname{Prp}$

0.056

0.275

0.275

0.059

159
0.684
0.260
0.056

161
0.689
0.252
0.059

163
0.697
0.245
0.058

164
0.692
0.252
0.056

166
0.690
0.254
0.056
Mean
$(n=8)$
0.683
0.260
0.057

$\begin{array}{rr}\begin{array}{r}\text { Low Ca Grt } \\ \text { Overall } \\ \text { Mean }\end{array} & \text { Std Dev } \\ \begin{array}{r}(\mathrm{n}=13) \\ 0.654\end{array} & 0.039 \\ 0.290 & 0.040 \\ 0.057 & 0.006\end{array}$

0.057

0.006 
Table 3. Calculated Liquid Compositions at locations on P-T path

\begin{tabular}{|c|c|c|c|c|c|c|}
\hline & $03-126$ & & & $03-127$ & & \\
\hline & $\operatorname{Liq} \mathrm{A}$ & Liq B & Liq C & Liq A & Liq B & Liq C \\
\hline$P(G P a)$ & 2.3 & 1.55 & 1.25 & 2.3 & 1.55 & 1.1 \\
\hline $\mathrm{T}\left({ }^{\circ} \mathrm{C}\right)$ & 945 & 900 & 800 & 945 & 900 & 790 \\
\hline $\mathrm{SiO} 2$ & 62.58 & 64.75 & 64.99 & 62.45 & 63.74 & 65.86 \\
\hline $\mathrm{Al} 2 \mathrm{O} 3$ & 16.51 & 15.62 & 14.48 & 16.60 & 14.47 & 13.81 \\
\hline $\mathrm{FeO}$ & 1.59 & 1.46 & 0.91 & 1.61 & 3.74 & 1.35 \\
\hline $\mathrm{MgO}$ & 0.39 & 0.40 & 0.21 & 0.35 & 0.98 & 0.25 \\
\hline $\mathrm{CaO}$ & 1.35 & 1.64 & 0.86 & 1.47 & 1.40 & 0.83 \\
\hline $\mathrm{Na} 2 \mathrm{O}$ & 7.13 & 3.83 & 4.15 & 7.03 & 4.18 & 3.60 \\
\hline K2O & 1.95 & 5.10 & 5.02 & 2.00 & 4.46 & 5.46 \\
\hline $\mathrm{H} 2 \mathrm{O}$ & 8.5 & 7.21 & 9.38 & 8.48 & 7.04 & 8.84 \\
\hline Total & 100.00 & 100.01 & 100.00 & 99.99 & 100.01 & 100.00 \\
\hline $\mathrm{Na}_{2} \mathrm{O}+\mathrm{K}_{2} \mathrm{O}$ & 9.08 & 8.94 & 9.17 & 9.03 & 8.64 & 9.06 \\
\hline $\mathrm{Na}+\mathrm{K}$ anh & 9.92 & 9.63 & 10.12 & 9.87 & 9.29 & 9.94 \\
\hline $\mathrm{Na}_{2} \mathrm{O}+\mathrm{K}_{2} \mathrm{O} / \mathrm{Al}_{2} \mathrm{O}_{3}$ & 0.84 & 0.76 & 0.85 & 0.83 & 0.81 & 0.86 \\
\hline $\mathrm{Al}_{2} \mathrm{O}_{3} /\left(\mathrm{Na}_{2} \mathrm{O}+\mathrm{K}_{2} \mathrm{O}+\mathrm{CaO}\right)$ & 1.01 & 1.05 & 1.05 & 1.01 & 1.02 & 1.04 \\
\hline
\end{tabular}

